\title{
The Social Lives of Products: \\ Analyzing Product Demography for Management Theory and Practice
}

GLENN R. CARROLL*

Stanford University

OLGA M. KHESSINA

Cornell University

DAVID G. MCKENDRICK

Australian National University

\begin{abstract}
Despite the centrality of products in many strategic and managerial theoretical frameworks, little is known systematically about how and why specific products come and go from markets. We argue that narrowing this gap will likely enhance management theory, and we propose that research on product demography-the social lives of products-is a promising way to proceed. For organizing various theoretical ideas used in prior studies, we offer a classification framework. It defines four broad theoretical perspectives on product demography: market rationality, firm rationality, organizational bounded
\end{abstract}

*Corresponding author. Email: carroll_glenn@gsb.stanford.edu

ISSN 1941-6520 print/ISSN 1941-6067 online

(C) 2010 Academy of Management

DOI: $10.1080 / 19416521003732362$

http://www.informaworld.com 
rationality, and institutional rationality. We also outline an approach to product demography that studies empirically the rates of product launch, growth, and withdrawal using stochastic models and data on all products ever appearing in bounded industrial domains. Finally, we discuss the challenges presented by such a fragmented approach to research on product demography and propose a generic research program intended to avoid stagnation.

\section{Introduction}

Organizations compete on a number of dimensions and in a variety of different markets. Yet no dimension of competition plays a larger role in theories of strategy and organization than product competition in the product market. For instance, product competition forms the basis of Porter's (1979) highly influential theory of strategic management, the core conceptual problem of makeor-buy decisions in transaction cost economics (Williamson, 1975) and the evidence used to support life-cycle theories of industry evolution (Klepper, 1996).

Product dynamics and product strategies also take center stage in marketing research. Marketing scholars attend to a wide variety of product-strategy issues including product life-cycle management (Shankar, Carpenter, \& Krishnamurthi, 1999), product line management (Randall, Ulrich, \& Reibstein, 1998), new product introduction (Shankar, 1999), order of product market entry (Boulding \& Christen, 2003), product performance (Bridges, Kim, \& Briesch, 1995), product-level competition (Kuester, Homburg, \& Robertson, 1999), and product displacement and obsolescence (Levinthal \& Purohit, 1989).

Given this theoretical centrality of product-based phenomena, we find it remarkable that empirical knowledge of dynamic product behavior in a market-the coming and going of products, their actual social lives-is highly limited. As Bayus (1998, p. 764) lamented a little over a decade ago, "very limited empirical information on product lifetimes for any particular industry is available in the literature." While (as we review below) the interim has seen more systematic information and analysis on product lifetimes, we believe that study of the phenomena is still greatly underdeveloped relative to its potential importance.

This is not to say that studies using product data do not appear in the journals of economics, management, and marketing. Indeed, many do. The bulk of studies that do use product data, however, typically involve aggregations about classes or kinds of products rather than specific products defined by companies and consumers (we review exceptions to this pattern below). For instance, theory and research on the product life cycle (e.g., Abernathy \& Utterbuck, 1978; Jovanovic \& MacDonald, 1994; Lambkin \& Day, 1989; McGahan, Argyres, \& Baum, 2004) examine the temporal trajectory of all producing companies' aggregated output of a kind or class of product. So, rather than study the product experiences of individual companies (in terms of when 
they launch and withdraw specific products), the product life-cycle approach examines the combined experience of all producers with consumers for a product class. While informative, we think that this aggregated life-cycle approach yields more knowledge about markets than firms, thus missing an opportunity to develop management theory and research. In particular, we think that research on product demography can potentially provide lasting insight into the adaptability of firms and the conditions that foster or impede it. After all, a major way that firms attempt to adapt to changing circumstances is through the launching and withdrawal of products.

This review essay proposes a generic research program devoted to addressing this gap in knowledge on the dynamics of individual product behavior. It argues for examining comprehensive product demography among all firms in a worldwide market over its entire early development and almost all of its history. Empirical analysis would investigate and model the demography of all products of all firms that ever participated in the industry. Product demography features the rates at which organizations typically launch and withdraw products from the market, their lifetimes, as well as the growth rate of products offered on the market. Among other reasons, we think that such information is potentially interesting in its own right because it provides a unique window onto the structure and variability of consumption patterns in advanced consumer society.

Is product demography a specialized topic best analyzed within marketing and economics or is it potentially informative to management generally? We think that development of a broad comparative base of systematic empirical facts and relationships about product demography will be useful generally in understanding how products affect organizations and vice versa. A good point of reference is human demography or population studies. In that field, comparisons of human morbidity and mortality rates across different industrial and geographic contexts often point to places of abnormally high or low rates deserving of more detailed scrutiny with respect to safety, nutrition, sanitation, pollution, healthcare, and the like. Likewise, product demography should uncover contexts with unusually high or low rates of product disappearance, and these patterns would likely be clues to important underlying behavioral and organizational differences that should be investigated in greater depth. ${ }^{1}$ In addition to informing about consumption and organizational adaptability, we imagine that such studies could potentially provide insight into thorny research questions about micro-macro aggregation mechanisms because individual and group decisions about products often exert an impact on the whole firm and beyond; conversely, the structure of the firm conditions managerial decisions about products.

The essay proceeds as follows. We begin by reviewing and commenting on the variety of extant theoretical ideas that typically arise when analysts attempt to explain patterns of product demography. In the following sections, we 
outline our view of how research in this area might proceed from this point. We start by describing the necessary components of a research program on product lives, including the appropriate models. We then ask what a product is and propose a way that analysts might go about identifying it. In the final section, we suggest a generic way to develop an empirical research program that we think would lead to cumulative knowledge about product demography.

\section{Theoretical Perspectives on Product Demography}

The earliest product demography study we can identify is Connor's (1981) look at the determinants of all branded food and beverage product introductions in the U.S. food sector in 1977-1978. However, the first study that systematically examined product entry and exit in modern demographic fashion-analyzing all products over almost the whole period of industry development-is Stavins's (1995) examination of the U.S. personal-computer industry from 1976-1988. Table 1 lists the published studies in product

Table 1 Empirical Studies in Product Demography

\begin{tabular}{|c|c|c|}
\hline Study & Industry and Time Frame & $\begin{array}{l}\text { Population/ } \\
\text { Sample }\end{array}$ \\
\hline Asplund and Sandin (1999) & Swedish beer market, 1989-1995 & All new products ${ }^{a}$ \\
\hline Astebro and Michela (2005) & $\begin{array}{l}\text { Inventions reached the market } \\
\text { from the Inventor's Assistance } \\
\text { Program in Canada, 1989-1993 }\end{array}$ & Sample \\
\hline Bayus (1998) & $\begin{array}{l}\text { U.S. personal-computer } \\
\text { industry, 1974-1992 }\end{array}$ & All products \\
\hline Bayus and Putsis (1999) & $\begin{array}{l}\text { U.S. personal-computer } \\
\text { industry, 1981-1992 }\end{array}$ & All products \\
\hline Chisholm and Norman (2006) & $\begin{array}{l}\text { Movies run at theaters in the } \\
\text { Boston metropolitan market, } \\
\text { Jun } 30,2000 \text {-Jun } 28,2001\end{array}$ & Sample \\
\hline Connor (1981) & $\begin{array}{l}\text { Branded food and beverages } \\
\text { market, 1977-1978 }\end{array}$ & All new products \\
\hline Cottrell and Nault (2004) & $\begin{array}{l}\text { Microcomputer software } \\
\text { industry, 1981-1986 }\end{array}$ & All products \\
\hline de Figueiredo and Kyle (2006) & $\begin{array}{l}\text { Laser-printer industry, 1986- } \\
1996\end{array}$ & All products \\
\hline Greenstein and Wade (1998) & $\begin{array}{l}\text { Mainframe-computer industry, } \\
\text { 1968-1982 }\end{array}$ & All new products \\
\hline Fontana and Nesta (2006) & LAN-switch market, 1993-1999 & Sample \\
\hline
\end{tabular}


Table 1 Empirical Studies in Product Demography (Continued)

\section{Study}

Fosfuri, Giarratana, and Luzzi (2008)

Hitsch (2006)

Iizuka (2007)

Ingram and Roberts (1999)

Khessina and Carroll (2008)

Moral and Jaumandreu (2007)

Putsis and Bayus (2001)

Requena-Silvente and Walker (2005)

Requena-Silvente and Walker (2009)

Rosa, Judson, and Porac (2005)

Ruebeck $(2002,2005)$

Sorenson, McEvily, Ren, and Roy (2006)

Sorenson, McEvily, Ren, and Roy (2006)

Stavins (1995)

\section{Industry and Time Frame}

Open-source-software industry, 1980-2003

\section{U.S. ready-to-eat breakfast-cereal Sample} industry, 1988-1990

U.S. textbooks used in economics courses, 1996-2000

U.S. pharmaceutical industry, 1978-1993

Worldwide optical-disk-drive industry, 1983-1999

Spanish car registration (sales), Jan 1990-Dec 1996

U.S. personal-computer industry, 1981-1992

UK automobile market, Jan 1971Dec 1998

UK automobile market, 19712002

Motorcycle industry, 1990-1996

Hard-disk-drives industry, first quarter of 1991-the last quarter of 1993

U.S. machine-tool manufacturing, 1975-1995

U.S. computer workstations, 1980-1996

U.S. personal-computer industry, All products 1976-1988
Population/ Sample

All new products

All products

All products

All products

All new products

All products

All new products

All new products

Sample

All products

All new products

All products

\footnotetext{
a"All new products" means that only products that were introduced since the first year of data observation are included into analyses. Researchers use this strategy to mitigate left-censoring issues that arise in a data that does not go all the way back to the beginning of an industry.
} 
demography that we were able to find across the marketing, economics, and management literatures. The table provides information on the nature of data used for empirical analysis, such as industry under study, period during which the industry was observed, and whether the data covered the whole population of products in a given industry or only a sample. While covering a range of industries, the studies do slightly tend to favor modern highertechnology settings.

Research on product demography uses a veritable smorgasbord of theoretical ideas. Some analysts emphasize the appeal of products to their potential buyers relative to competitor products, others emphasize the context of a product within a firm's strategy and product portfolio, and still others emphasize the organizational incentives and political processes possibly operating through product demography. Often these points of emphasis arise in motivating particular independent variables rather than in any coherent or consistent theoretical approach. The result is a crowded and diverse deli-style menu of possible explanatory factors behind product demography. Nonetheless, we think the explanations advanced in these studies typically draw (often implicitly) on any of four different broad theoretical perspectives, each carrying along its own set of (often different) assumptions. These are: a perspective of products as market rationality; a perspective of products as firm rationality; a perspective of products as organizationally bounded rationality; and a perspective of products as institutional rationality. We review each in turn. On occasion, this exercise involves filling in the story with specific mechanisms linking empirically associated distal "causes" with demographic events; in some cases, we recognize that other mechanisms might be used to do this, and these could lead to classification under a different perspective.

\section{Products as Market Rationality}

Within this perspective, the lifetime of a product is theorized as the outcome of market forces supporting its existence. The characteristics of the product itself and the market demand it faces are the main sources of product viability and longevity. Vital events are often described within this perspective as product entry, disappearance, survival, and failure. The products analyzed are considered relatively independent entities that individually depend on meeting market demands and tastes; it is as though no firm or organization operates behind their launch or withdrawal. Scholars who work in this perspective focus their attention on two major themes: product characteristics and market characteristics.

Product characteristics. Analysts find time and time again that several important characteristics of a product affect its ability to meet market demands and thus determine its longevity. A primary characteristic receiving thorough attention is product age, defined as the time that a product has been 
on the market since its appearance. As products age, theorists suggest, they tend to become obsolete in terms of both objective characteristics like technical performance (Cottrell \& Nault, 2004) and disembodied attributes like "newness" or "latest design" (Moral \& Jaumandreu, 2007). As a result, aging products do not satisfy consumer preferences as well as they did and therefore disappear from the market faster than newer products (Cottrell \& Nault, 2004; Greenstein \& Wade, 1998). The effect of product age on its survival is widely accepted; it is one of few factors consistently controlled for across different product-survival studies (de Figueiredo \& Kyle, 2006; Fosfuri, Giarratana, \& Luzzi, 2008; Hitsch, 2006; Iizuka, 2007; Khessina \& Carroll, 2008; RequenaSilvente \& Walker, 2005, 2009; Ruebeck, 2002, 2005; Stavins, 1995).

Product performance or quality, often defined by technical parameters of the product, also predicts product survival. Researchers theorize and find that products with performance close to the technological frontier appeal more to customers and therefore stay on the market longer (Astebro \& Michela, 2005; de Figueiredo \& Kyle, 2006; Khessina \& Carroll, 2008; Requena-Silvente \& Walker, 2009; Ruebeck, 2005; Stavins, 2005). In the laser-printer industry, de Figueiredo and Kyle (2006) also demonstrate that proximity to the technological floor can be advantageous to longevity. This apparently happens because technologically inferior products carry lower prices and appeal to unsophisticated, price-sensitive consumers. Additionally, not only product technical performance but also the generic technology that a product embodies affects its survival: products based on older technologies have significantly shorter lifetimes (Bayus, 1998).

Cottrell and Nault (2004) speculate that products with functional variety (e.g., software that combines a word processor and a spreadsheet) achieve better performance than products with only a single application in markets with economies of scope in consumption. In the software industry, they find that products covering a greater number of applications and operating under a greater number of operating platforms stay on the market longer (Cottrell \& Nault, 2004).

Since customers prefer to avoid overpaying, higher-priced (adjusted for quality) products should disappear from the market at a greater rate. Using residuals from hedonic regressions (which break down and evaluate the appeal of a product in terms of its constituent attributes), researchers have shown that overpriced products indeed have a higher probability of disappearing (de Figueiredo \& Kyle, 2006; Stavins, 1995). However, Ruebeck (2005) did not find any difference in exit rates between overpriced and underpriced products.

When products do not meet market demands, they fail to gain market share and may even lose their existing market share. Products with low or decreasing market share disappear at higher rates (Asplund \& Sandin, 1999; Ruebeck, 2002). 
Some conventional wisdom holds that product life cycles get systematically shorter over time; however, empirical studies fail to confirm this pattern (Bayus, 1998; Greenstein \& Wade, 1998; Stavins, 1995). Nonetheless, Khessina and Carroll (2008) found that after controlling for product entry, products entering later in an industry display higher exit rates (Khessina \& Carroll, 2008); another study found an inverted U-shape relationship between the order of product entry and product exit (Requena-Silvente \& Walker, 2009).

Market characteristics. The impact of product characteristics on product vital rates also depends on their congruence with the market, especially consumer demand. Theorists reason that demand is positively related to product entry (Connor, 1981) and negatively related to product disappearance (Astebro \& Michela, 2005). Indeed, high product-entry rates associate empirically with high demand (Connor, 1981) and with large market size (Ingram \& Roberts, 1999). Likewise, low product disappearance rates correspond with high demand (de Figueiredo \& Kyle, 2006), low demand uncertainty (Astebro \& Michela, 2005; Hitsch, 2006), high initial revenues (Chisholm \& Norman, 2006), and high sales and shipments in complementary and symbiotic industries (Cottrell \& Nault, 2004; de Figueiredo \& Kyle, 2006; Khessina \& Carroll, 2008).

Industry structure also affects product demography (Connor, 1981; Greenstein \& Wade, 1998). Industry structure includes a set of interrelated factors such as entry barriers, competition, industry concentration, threat of substitutes, buyer power, and so on (Porter, 1980). While we know of no comprehensive analysis of industry structure and product demography, researchers have uncovered effects of several relevant factors. For example, product entry increases when: entry barriers are low and market opportunities exist (Putsis \& Bayus, 2001); competition is low and threat from substitutes is small (Greenstein \& Wade, 1998); and sales are moderately concentrated and advertising intensity is high (Connor, 1981). Moreover, products tend to stay on the market longer when average price in the industry is high (Astebro \& Michela, 2005) and when densities of competing and substitute products are low (Greenstein \& Wade, 1998). Proliferation of patents does not affect product failure rate, but standardization improves product survival (Khessina \& Carroll, 2008).

The most studied factor of industry structure concerns competition with other products, including those of the focal firm; indeed, product competition receives paramount interest within the market-rationality perspective. Overlap and substitutability are key ways to think about competition. Consumer or buyer tastes explain the launch and demise of products, as well as their relative growth rates. The core insight here holds that competitive pressures create a shortage of consumer attention for uncompetitive products, driving them out of the market and preventing the entry of new ones. Empirically, the main 
finding shows that competition, measured by the number of all products made by all firms on the market, decreases product entry (Greenstein \& Wade, 1998; Ingram \& Roberts, 1999) and increases product exit (Astebro \& Michela, 2005; Cottrell \& Nault, 2004; Greenstein \& Wade, 1998; Khessina \& Carroll, 2008; Requena-Silvente \& Walker, 2009).

Market segmentation can also shape product demography (Greenstein \& Wade, 1998). Studies show that product vital rates significantly differ across market segments, niches, and submarkets (Iizuka, 2007; Khessina \& Carroll, 2008; Requena-Silvente \& Walker, 2005, 2009). Additionally, adjacent product niches competitively affect product demography of a focal niche, such that the number of products in an adjacent niche increases product failure in a focal niche (Greenstein \& Wade, 1998). But proposed segmentation explanations often rely on idiosyncrasies of the industries studied.

In general, the market-rationality perspective appeals to many product analysts and is commonly used in product demography. But we also suggest that despite the ultimate focus on the market performance of products, this perspective carries exaggerated importance. Products seem to us less tightly connected to markets in the short run-performance takes some time to evaluate and equilibrium takes some time to obtain. In the meantime, the landscape of many markets is cluttered with products that will ultimately prove unsuccessful by this test (Khessina, 2006). If so, then many, if not most, demographic events of products can be explained by factors drawn from other perspectives.

\section{Products as Firm Rationality}

Within this perspective, theories explain product entry, growth, and longevity by resorting to characteristics of the producer firm and its competitive position. In other words, explanatory factors derive from a higher level of aggregation-the firm typically rather than the product. The assumptions carried in this perspective imply that product demography reflects managerial actions intended to optimize the firm's competitive chances, not the individual product's viability or longevity. Accordingly, aspects of product portfolio take on central importance, and vital events are typically referred to as product launches and withdrawals, terms implying human agency. In general, scholars working from this perspective focus their attention on four major themes: firm competition, firm strategic responses to competition, product portfolios, and firm strategic characteristics.

Firm competition. Scholars who work on product demography from the firm-rationality perspective use competition differently than those coupling competition with market rationality. Instead of claiming that competition impacts product vital rates directly (Greenstein \& Wade, 1998; Ingram \& Roberts, 1999), these scholars consider competition a factor that firms take 
into account when making decisions about their product portfolios (de Figueiredo \& Kyle, 2006; Stavins, 1995). As de Figueiredo and Kyle (2006, p. 245), put it, "a decision to exit [a product] does not necessarily mean that a product has 'failed' [in competition]. It merely means that a profit-maximizing manager has determined that the current product portfolio is not the profit-maximizing one, and that alterations need to be made." Additionally, de Figueiredo and Kyle (2006) distinguish among three types of interfirm competition-market crowding, market contestability, and substitutabilityand one type of intrafirm competition-cannibalization.

When managers view competition as market crowding, they use information on the number of all products (of all firms) on the market to explain their products' current profits and predict future ones. The greater the number of products on the market, the more likely a focal product has a low price-cost margin, and thus brings low returns (Ruebeck, 2002). Managers usually decide to launch a new product when they expect positive returns, such as in less-crowded markets, and withdraw an existing product when it starts generating negative returns (de Figueiredo \& Kyle, 2006). Empirical studies confirm that product launch rates decrease and product withdrawal rates increase with the number of total products on the market (de Figueiredo \& Kyle, 2006; Ruebeck, 2002, 2005).

Another aspect of interfirm competition is related to market contestability. Forbearance and other strategic considerations play a key role here. A firm may decide to introduce products into crowded niches (Connor, 1981) and keep products with zero or negative profits on the market (Ruebeck, 2002). Why? One reason involves continued contesting of existing competitors, apparently to keep them distracted (Chisholm \& Norman, 2006). Another reason is simply to attempt to deter entry by new firms (Khessina \& Carroll, 2008). For example, Bayus and Putsis (1999) show that a firm is more likely to launch new products when competitors broaden their product lines. Contestability is also found among companies located in the same geographic vicinity. The presence of a competing movie theater in the same neighborhood increases the life of a film at a focal theater (Chisholm \& Norman, 2006).

Preemptive product strategies can be observed by examining product behavior of incumbents and entrants (Fontana \& Nesta, 2006; Stavins, 1995). The underlying theoretical idea comes from economics. It posits that the threat from potential entrants motivates incumbents to undertake one of the following strategies: to introduce close substitutes for their existing products in order to prevent new firm entry into their segments (Schmalensee, 1978); or to disperse their products in the quality space in order to preempt the entire market (Bonanno, 1987; Spence, 1976). Because of this preemptive excessive crowding by incumbents, new entrants are forced to introduce their products in empty, peripheral market space, and they usually concentrate them in a single market segment (Bonanno, 1987; Schmalensee, 1978). 
Product-demography research confirms these predictions. It finds that incumbents locate their products close to existing ones, but when threatened by entrants, they locate their products far from the crowd (Fontana \& Nesta, 2006; Stavins, 1995). As for entrants, in the U.S. personal-computer industry, they position products in crowded market segments (Stavins, 1995), but in the LAN-switch industry, in less crowded, low-end segments (Fontana \& Nesta, 2006). Product dispersion between entrants and incumbents shows no difference in the U.S. personal-computer industry, but more experienced firms do disperse their products in quality space (Stavins, 1995). However, in the LAN-switch market, incumbents disperse their products more than entrants (Fontana \& Nesta, 2006). Finally, the products of entrants exit the market at a higher rate than the products of incumbents (Stavins, 1995).

The firm-rationality perspective's third take on inter-firm competition examines substitute products. The approach is again different from the substitutability concerns of the market-rationality perspective, which focuses on direct effects of substitute products on product vital rates (Greenstein \& Wade, 1998). Instead, analysts here examine factors that affect a firm's decision to introduce substitute products (Iizuka, 2007). For instance, in the U.S. economics-textbook market, a publisher will likely decide to revise an edition (i.e., will introduce substitutes for both its own and rival products) when its gets old, when the number of used books garners significant market share, and when the book sells in a large target market (Iizuka, 2007).

Intrafirm competition, or cannibalization, refers to the negative impact that a firm's own (closely located) products have on each other. When a firm produces several products located in the same product space, it may decide to withdraw a product even while it is generating positive profits. Since withdrawing some of its own competing products may increase firm-wide profits, such a strategy helps the firm internalize cross-price effects among its nearby products (Ruebeck, 2005). Conversely, a firm may decide to postpone or even drop the launch of a potentially attractive new product if its predicted effect might cannibalize a currently successful (or high-profile, image-generating) product of the firm. Reasoning of this kind centers on optimizing the performance of an overall product portfolio rather than any individual product. Studies show as the number of a firm's own products on the market increases, so does the likelihood of it withdrawing a product (Chisholm \& Norman, 2006; Cottrell \& Nault, 2004; Greenstein \& Wade, 1998; Requena-Silvente \& Walker, 2005, 2009; Ruebeck, 2002, 2005). Ruebeck $(2002,2005)$ also find that cannibalization exerts a stronger effect on product withdrawal than interfirm competition.

Firm strategic responses to competition. Despite the dangers of product cannibalization, some firms decide to extend their product lines. As discussed above, strategically induced forbearance can be one reason (Connor, 1981; 
Stavins, 1995). Another reason involves firms' attempts to take advantage of perceived strategic opportunities, such as low barriers to entry, for example, low industry concentration and low market-wide new-product activity (Putsis \& Bayus, 2001). Firms' decisions to extend their product lines and the magnitude of this extension are driven by different factors.

As industries evolve, it becomes important for firms to expand product variety to increase their product-differentiation advantages (Porter, 1980). In particular, product differentiation and product dispersion may help firms to obviate negative effects of increasing competition. Requena-Silvente and Walker (2009) find that both product differentiation and product dispersion decrease product-hazard rates, with dispersion having a stronger effect. In Cottrell and Nault's (2004) study, diversification into new categories of products generates a mostly negative effect on product longevity, but dramatic diversification into a completely new category of products increases product survival.

The extent to which a firm focuses on very few applications or diverts its attention to many applications that its products embody may affect its product demography. In the software industry, products of firms that make products in multiple applications and under multiple platforms are withdrawn at a higher rate. Cottrell and Nault (2004) speculate that this happens because firms that work across multiple product categories are too unfocused to create high-quality products.

Product portfolio. In general, by changing their product portfolios, firms change the vital rates of their products. Entry of new products impacts their own fates and those of existing products. Withdrawal of products may affect the launch of new products. Although it seems logical to think that productlaunch and withdrawal decisions connect tightly, empirical research fails to confirm this prediction (Greenstein \& Wade, 1998; Ruebeck, 2005). Researchers also find different drivers behind decisions to expand and decrease product lines (Putsis \& Bayus, 2001). Moreover, firms tend to introduce new products at a higher rate than they withdraw their older products (Bayus \& Putsis, 1999).

A firm's decision about changing its product portfolio can be based on its experiential learning in the market. Because of the often unpredictable nature of consumer demand, some scholars contend that firms can only learn about consumer preferences over time. By this view, firms introduce a new product and wait to gauge consumer reaction. Firms then can estimate the cost of keeping the product on the market and its future demand from observed sales. By this strategy, firms may launch an occasional unprofitable product but do not miss potentially profitable ones (Hitsch, 2006). Supporting this speculation, Hitsch (2006) finds that the average profitability of new products is lower than that of all products on the market, and that product exit is positively 
related to the initial advertising-to-sales ratio. Asplund and Sandin (1999) find that firms tend to withdraw products when sales trend downward.

Firm strategic characteristics. Strategic characteristics of a firm predict what product strategy a firm will likely undertake. We have already discussed what product strategies entrants and incumbents pursue. A firm's market power, defined by its market share, is another factor in understanding product behavior. Theory suggests that firms with greater market share tend to have a more heterogeneous customer base (de Figueiredo \& Silverman, 2007). To address preferences of diverse customers, such firms need a broader product line (Bayus \& Putsis, 1999). Firms with higher market share can also promote their new products better (Connor, 1981). Finally, firms with larger market share may use broader product lines as a defensive strategy to protect an achieved market position (Putsis \& Bayus, 2001). Given these tendencies, firms with high market share are expected to launch more products and withdraw fewer products. Indeed, empirical studies show that the higher a firm's market share, the more likely it is to extend its product line (Bayus \& Putsis, 1999; Connor, 1981; Putsis \& Bayus, 2001). Firms with larger market share are also shown to withdraw fewer products (de Figueiredo \& Kyle 2006; Putsis \& Bayus, 2001; Ruebeck, 2002), but one study found the opposite (Asplund \& Sandin, 1999).

Firms with strong brands can capture higher price premiums on brand extensions into nearby classes, extend their product lines with limited cannibalization effects, and exercise economies of scope. Strongly branded firms thus possess motivation to introduce new products at a higher rate and keep them on the market for longer than weakly branded firms (de Figueiredo \& Kyle, 2006). Empirical studies reveal inconsistent findings about product launch. Firms with strong brands introduce more products in the mainframecomputer industry (Greenstein \& Wade, 1998), but fewer products in the laser-printer industry (de Figueiredo \& Kyle, 2006). However, strongly branded firms do seem to keep products on the market for longer (de Figueiredo \& Kyle, 2006; Greenstein \& Wade, 1998; Ruebeck, 2002, 2005). Reputation brings similar advantages. Products of firms with a high reputation, defined as either older firms or pioneering firms, are more dispersed along the quality space and stay on the market longer (Stavins, 1995).

In our assessment, firm rationality commands the most popularity among the perspectives, and it gets used the most frequently. This is not surprising. The perspective goes a long way by explaining product demography as an outcome of firms' reactions to market conditions, rather than assuming that the market affects product vital rates directly without any input from firms, as the market-rationality perspective holds.

Despite its obvious strengths, the firm-rationality perspective cannot explain why firms that possess similar strategic characteristics and undertake 
similar product strategies in response to similar competitive conditions may exhibit different product-demography outcomes. We think that this happens because even when firms intend to be rational, they are at best only limitedly so. Internal organizational structures and processes prevent many organizations from behaving in an optimal way and fully implementing intended product strategies. Thus at least some demographic events of products can be explained by factors drawn from the third and fourth perspectives.

\section{Products as Organizational Bounded Rationality}

Within this perspective, product demography reflects the outcome of individuals and groups within the organization exercising bounded rationality with respect to their lives and careers or operating units. There is no one rationality for the entire organization (as is the case for the firm-rationality perspective discussed above) but many different rationales depending upon the task to be done and the individuals and groups involved. Product events might be the consequence of incentives for careers of individuals. Powerful units and individuals might promote their own products and suppress those of others. Some products might get launched as a response to inertia. In what might be called "work arounds," products might be the response of some units' failure to get their agendas implemented and to change the existing products of a firm (recall the popular book by Kidder, 1982, about Data General). This behavior need not be reactive or dysfunctional. Work groups may develop routines and capabilities that lead to particular kinds of product strategies, or internal R\&D competition might determine which products get launched and promoted.

Compared with the market- and firm-rationality approaches, this perspective is far less developed in explaining product demography. Although the studies discussed below theoretically associate product demography with the internal processes of the firm, they typically do not measure these processes directly. Organizationally bounded rationality explanations of product demography typically are cast at a level of aggregation higher than the product (presumed in market rationality) but lower than the firm (presumed for firm rationality). Researchers working in this perspective focus on two major themes: firm capabilities and internal organizational processes.

Firm capabilities. A firm's development and successful implementation of a product strategy is constrained by its capabilities. At a very general level, firm capabilities are understood as a set of organizational routines related to a firm's ability to deploy resources using organizational processes to achieve a desired end (Amit \& Schoemaker, 1993). A given capability may or may not be tightly connected to a firm's strategy, and firms possessing several capabilities may find them in competition with each other for attention and resources. 
Firms may possess capabilities in innovation, manufacturing, marketing, distribution, and so on; each potentially affects product demography. The general consensus holds that capabilities, especially in innovation, increase a firm's ability to introduce new products, and especially in areas related to the capability base. It is also expected that products emanating from strong underlying capabilities will stay on the market longer because they are either inherently more appealing to customers or better promoted by the firm (Ingram \& Roberts, 1999; Khessina \& Carroll, 2008). Complementary assets or a set of related capabilities are predicted to have a similar effect on product demography.

Empirical studies of product demography using capabilities logic show that higher rates of product introduction run hand-in-hand with firms holding more patents (de Figueiredo \& Kyle, 2006; Fosfuri et al., 2008), firms garnering more product awards (de Figueiredo \& Kyle, 2006), firms with newer product lines (Putsis \& Bayus, 2001), firms with more experience in related markets, and firms diversifying into unrelated markets (Ingram \& Roberts, 1999). Capabilities also allow firms to locate their products more strategically in the product space. Thus firms more experienced in the related high-tech markets tend to locate their products closer to the frontier, while firms more experienced in the related low-tech markets tend to locate their products far from the frontier (Fontana \& Nesta, 2006). More experienced firms disperse their products in the product space (Stavins, 1995). Finally, lower rates of product withdrawal correlate with firms with more patents (Khessina \& Carroll, 2008), firms with narrow product lines (Putsis \& Bayus, 2001), and pioneering firms (Stavins, 1995).

The relationships between a firm's capability in achieving economies of scale and scope and its product vital rates receive special attention. Economies of scale in production, sales, and marketing help a firm reduce its costs for a given product. Since scale economies reduce costs for a product already on the market, it is more likely to survive. Supporting this prediction, de Figueiredo and Kyle (2006) show that products made by the top ten largest firms stay on the market longer.

When firms apply existing routines and capabilities across different industrial activities, they may gain economies of scope in production. Scope economies increase a firm's rate of product introduction in market segments located far from the crowd (Stavins, 1995), markets that are related to the focal market, and markets in which the firm participated in the past (Ingram \& Roberts, 1999). Firms with economies of scope, such as experienced organizations, also tend to disperse their products in the quality space (Stavins, 1995).

In certain situations, capabilities may become rigidities and affect product demography negatively (Ingram \& Roberts, 1999). For example, firms with more software trademarks launch fewer open-source software (OSS) products because they are concerned that introducing OSS products will reduce the trademark value of their proprietary software (Fosfuri et al., 2008). 
Capabilities put limits on what a firm can successfully do with its product portfolio. For example, a firm may intend to introduce new products on a regular basis to keep up with technological competition, but will fail to do so if it does not possess well-developed innovation capabilities.

Internal organizational processes. Within any given organization, group and department variations in social structure may affect implementation of an intended action. Differences in interdepartmental and intergroup incentives, rights, autonomy, career prospects, and access to other resources all affect subcultures, social networks, information flows, and political relationships, which in turn may have a dramatic constraining (or enabling) effect on how a firm both chooses a product strategy and succeeds at its implementation.

Studies in product demography do not directly measure such hard-to-see internal processes. Instead, researchers typically associate observable organizational characteristics with specific internal processes and structures theoretically. For example, organizational ecology suggests that as firms grow older, dysfunctional structures and processes develop, leading to political infighting, redundant organizational routines, dysfunctional departments and so onoutcomes of the so-called liability of senescence (Carroll \& Hannan, 2000). Accordingly, as organizations become older, the effectiveness of their decisionmaking processes decreases, and as a result, such firms miss opportunities or become slower to react, leading them to introduce fewer products and withdraw fewer products than would have been expected if they had been functioning effectively.

Khessina and Carroll (2008) propose that de novo and de alio firms differ in their organizational routines and structures. De alio firms, as structurally more complex and bureaucratic organizations, experience stronger inertial pressures. Sunk costs may attract more attention, and bureaucratic rationalizations may justify waiting for an unviable product to show a profit. This can explain why de alio firms' products show greater market longevity (Khessina \& Carroll, 2008). As de novo firms age, they too become more inertial. As a result, the difference in products demography between de novo and de alio firm diminishes over time (Khessina \& Carroll, 2008).

Other studies show that whereas firms with longer industry tenure are less likely to expand their product line (Putsis \& Bayus, 2001), they do carry products that exhibit higher market longevity (Cottrell \& Nault, 2004; Ruebeck, 2002, 2005; Stavins, 1995). In contrast to the inertia-based explanation (Khessina \& Carroll, 2008), alternative theorizing associates firm industry tenure with learning that helps firms achieve greater efficiency in decision making about their product portfolios. Older firms keep their products on the market longer because their experience helps them launch superior, if fewer, products and to discern better product future returns (Stavins, 1995). Studies 
examining more direct effects of organizational processes on product demography are needed to adjudicate between these conflicting explanations.

Many organizational processes vary by organizational size. Large size may indicate more developed capabilities and more abundant resources, but very large size is also often associated with structural inertia and rigidity. The predicted inverted U-shape relationship between firm size and product introduction, however, is not confirmed empirically (Ingram \& Roberts, 1999), nor is the relationship between firm size and product withdrawal (Khessina \& Carroll, 2008). However, Fosfuri et al. (2008) do find that larger firms introduce more products. While there could be several explanations for this finding, the organizational processes specific to large firms likely play a role. Given the importance of size in organizational theory and research, this issue clearly deserves more attention.

A firm's niche width may affect its product demography. Because generalist organizations tend to explore outside of their current niche to obtain broader scope, they develop routines and processes suitable to new product introduction. Thus Sorenson, McEvily, Ren, and Roy (2006) find empirically that generalists introduce more total products and more innovative products than more focused specialists firms.

The potential for both theoretical and empirical developments in the organizational-bounded-rationality perspective is high; we think many new ideas and data might be brought to bear on product demography. For instance, a promising theoretical vein might involve connecting organizational loose-coupling and opacity with product demography: all other things equal, we would expect tight-coupling and internal transparency to be associated with lower rates of product launches, since greater coordination would be required to initiate a product; the offering would also likely be rationalized throughout the organization. (Compare that to a loosely coupled decentralized organization where local managers can do as they please without regard for other units or sign-off from authorities.) Empirically, devising more precise measurement strategies of internal processes for populations of organizations over time will surely be challenging, but the result may help to adjudicate among conflicting explanations. Given its behavioral orientation, this perspective may also be central for developing meaningful distinctions among types of product starting (e.g., launch of internally developed products vs. introduction of products based on purchased technology) and ending events (e.g., product failure vs. product withdrawal because of upgrades made available by an R\&D department)_-so-called multiple destinations.

\section{Products as Institutional Rationality}

The institutional-rationality perspective ascribes an active role both to the market (in the form of audiences) and to the organization. It posits that product demography results from interactions between market audiences and 
firms (Hannan, Pólos, \& Carroll, 2007; Rosa, Porac, Runser-Spanjol, \& Saxon, 1999). During the ongoing "conversation," audiences and producers negotiate meanings and agree upon social categories that help to classify producers and their products. As Rosa Judson, and Porac (2005) put it, "product categories evolve as producers and consumers make sense of the perpetually changing variety of products available by summarizing, classifying, and labeling product attributes, uses and benefits" (p. 63). Researchers working in this perspective focus on two major themes: legitimation and social categories.

Legitimation. In organizational ecology, legitimation, or taken-forgrantedness, is an important driving force in early population evolution (Carroll \& Hannan, 2000). Legitimation operates simultaneously with competition. In the density model, legitimation increases with the number of firms in the population at a decreasing rate, whereas competition increases with the number of firms in the population but at an increasing rate. Thus the theory predicts non-monotonic relationships between organizational density and firm vital rates (an inverted U-shape for founding rates and a U-shape for mortality).

In a similar fashion, Ingram and Roberts (1999) suggest that product demography is driven by both legitimation and competition. Theoretically, as the number of products of a certain type increases, customers start to take it for granted and are more willing to buy it and use it; at the same time, other organizations start producing complementary products. Thus product vital rates should improve with an initial rise in product density (the number of all products in the market). Increasing product density further triggers competition for scarce consumer attention, and product vital rates should suffer. Ingram and Roberts (1999) report such an empirical pattern for introduction rates of pharmaceutical products.

Research on consumer acceptance also envisions a legitimation phase. Astebro and Michela (2005) argue that if consumers come to accept a new product, they are more likely to adopt it and buy it, improving its survival chances. Indeed, consumer acceptability of new products increases their survival (Chisholm \& Norman, 2006).

Recent developments in organizational ecology on organizational grade of membership (GoM) and fuzzy and contrast densities (Hannan et al., 2007) suggest that a more sophisticated approach to legitimation can be fruitful. It is possible that products made by firms with high GoM (i.e., firms with crisp membership in a focal industry) exert a stronger effect on legitimation than products made by firms with low GoM (i.e., firms with only partial membership). The former are more likely to focus the attention of audiences on a new product population than the latter. If this is true, then fuzzy product density should be a powerful predictor of product legitimation.

An unexplored issue involves the role of product names in product legitimation. Common, catchy names can be powerful in attracting attention of 
audiences. So, too, can mimicry of successful names. For example, in earlier years of soft-drink-industry development, the increasing number of products with "cola" in the name likely effectively focused attention of audiences on the new product population. By contrast, the dearth of similar product names among disk array producers made it difficult for audiences to recognize this new population (McKendrick, Jaffee, Carroll, \& Khessina, 2003).

National culture may also affect product legitimation. Significant variation in the types of firms that become taken for granted and are considered to be socially appropriate occurs across different national environments. The differences in imprinting and in regulatory, cognitive, and sociocultural pressures could affect product demography and result in different cross-national product vital rates. Indeed, firms with headquarters in Japan withdraw their products at a lower rate than companies located in other countries (Khessina \& Carroll, 2008).

Social categories. The principle of allocation for identity implies that firms that participate in multiple markets with products implying inconsistent or contradictory identities across social categories will suffer a penalty (Hsu, 2006; Zuckerman, 1999). ${ }^{2}$ By this view, if a firm with a product in a market launches a new product with a conflicting identity in another category, then both products will experience lowered growth and quicker failure. If the managers themselves understand the principle of allocation and behave accordingly, then their product launches will be less likely to involve products with conflicting identities and more likely to involve products with consistent identities.

An effect of a firm's identity on its product vital rates can be observed by comparing product behavior of de novo and de alio firms (Khessina \& Carroll, 2008). De novo firms possess a focused identity tightly linked to a focal market, whereas de alio firms often derive their primary identity from their parent companies. Key audiences, such as investors, employees, and consumers, thus likely have different expectations regarding product behavior of these two types of firms. In markets with technological competition, de novo firms are expected to stay at the technological frontier and maintain a product portfolio that reflects identity focused on the focal technology. They have to offer technologically advanced products, irrespective of whether the technological position improves actual market viability. De alio firms, whose identity is less tightly coupled with the focal market, likely do not experience such pressure. The pressure on de novo firms for faster product turnaround to keep up with the shifting technological frontier should result in better technical performance but shorter longevity of de novo firm's products. In the optical diskdrive industry, products of de novo firms possess better technological characteristics, but exit the market at a higher rate than those of de alio firms (Khessina \& Carroll, 2008). 
Khessina and Carroll (2008) also speculate that public and private firms may experience different identity pressures. Because public firms operate under greater social scrutiny than private companies, shareholders may expect them to behave in certain ways in specific industries. For example, in hightechnology industries, public companies may be pressured to offer products at the technological frontier, and thus turnaround their products faster. Empirical analysis confirms this prediction (Khessina \& Carroll, 2008).

Research suggests that not only identity of producers but also identity of products may affect product demography. Generally speaking, products with strong consistent identities should attract and keep the attention of consumers and other audiences, and thus survive longer. Indeed, products strongly associated with industry categories enjoy longer market survival (Rosa et al., 2005). Additionally, in markets with malleable category structures, products associated with more than one category apparently experience higher longevity (Rosa et al., 2005).

The potential of the institutional rationality perspective in explaining product demography remains virtually untapped. One possible new direction for research would involve analysis of a category's social value and categoryspecific fit of products (Sen \& Bhattacharya, 2001). For instance, in the contemporary world, sustainable or "green" products seem to enjoy popularity among consumers. What does it take to make a product appear validly sustainable to consumers? Does a product or firm suffer if it makes questionable claims about sustainability? How did the schema for sustainability develop over time? These are just a few of the types of interesting questions that might be explored about product categories and legitimation.

\section{Summing Up the Theoretical Perspectives}

The review of the four theoretical perspectives shows that although they are based on different and sometimes contradictory assumptions, productdemography studies usually draw on two or more of them, theoretically or empirically or both. Whereas a number of papers adhere theoretically to one or another perspective, very few empirical studies are exclusively based on one perspective (but see Astebro \& Michela, 2005, and Moral \& Jaumandreu, 2007, for "pure" market-rationality perspectives, and Fontana \& Nesta, 2006, and Fosfuri et al., 2008, for "pure" firm-rationality perspectives). No matter what the key theoretical perspective, many studies control for at least one of the market or product characteristics (from the marketrationality perspective) and features of firms (from the firm-rationality perspective).

Table 2 provides a summary of this review. We organize studies by the four theoretical perspectives. Within each perspective, we group articles first by key theoretical themes and then by more specific explanatory factors. We give an example of a prediction associated with each explanatory factor and list 


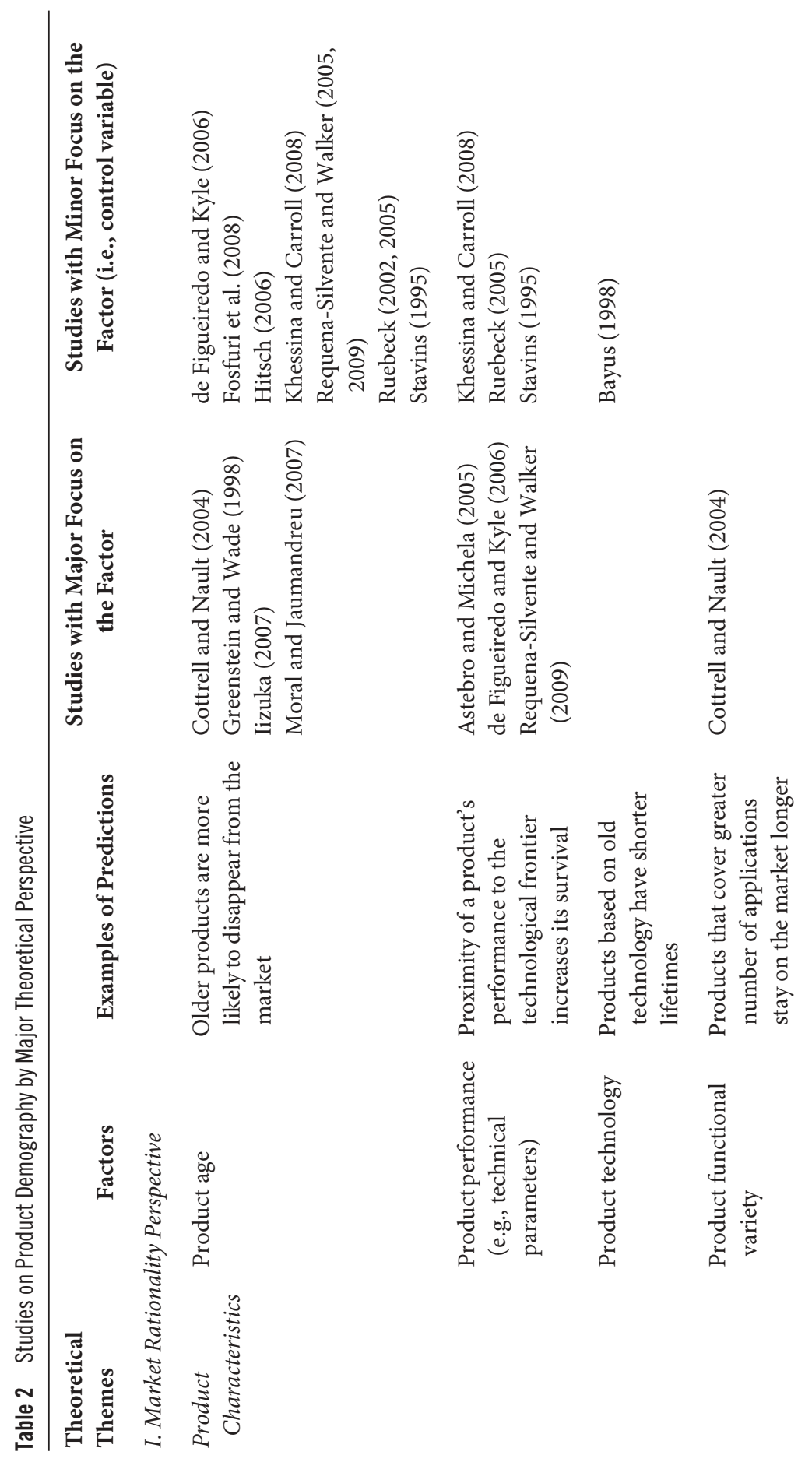


178 - The Academy of Management Annals

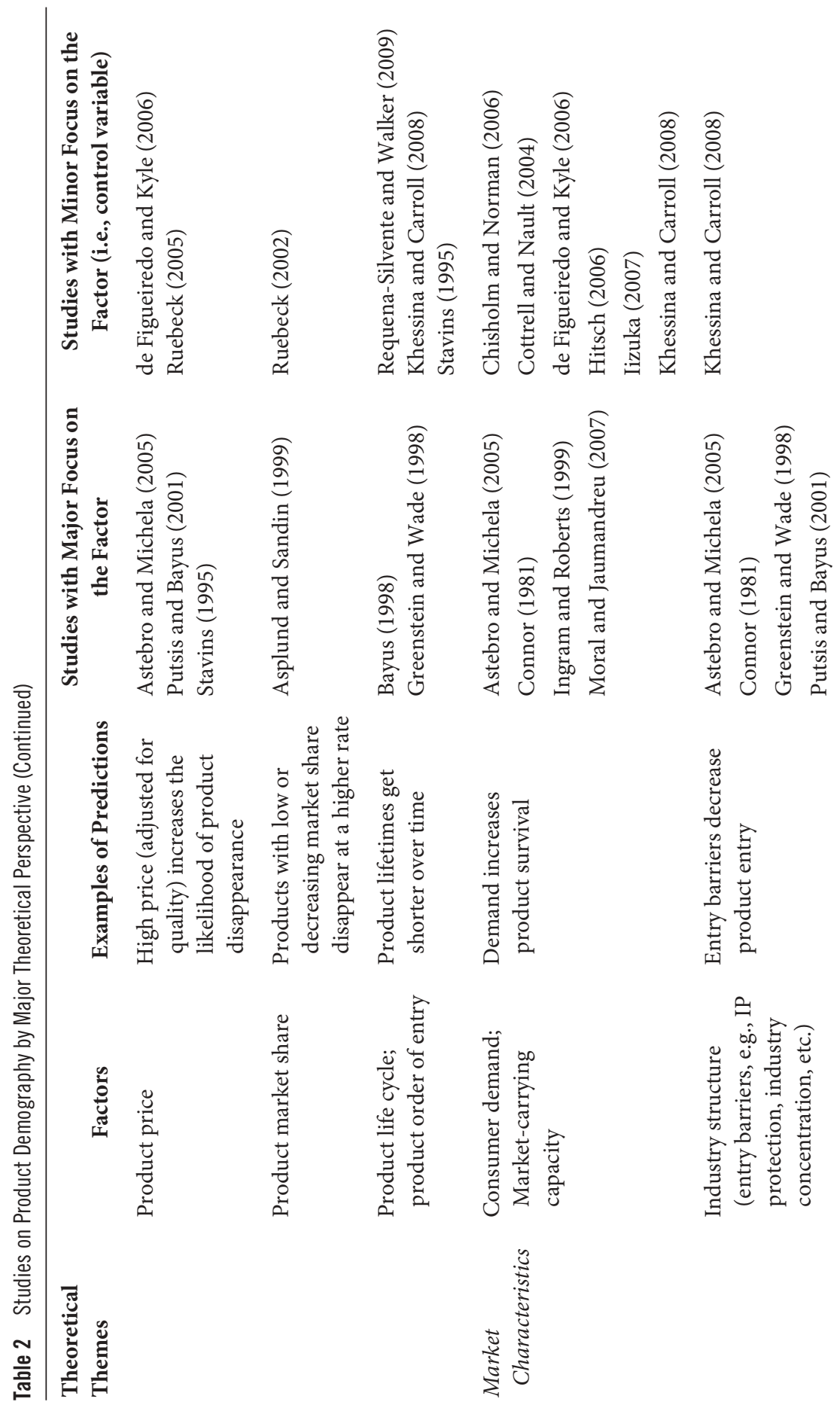



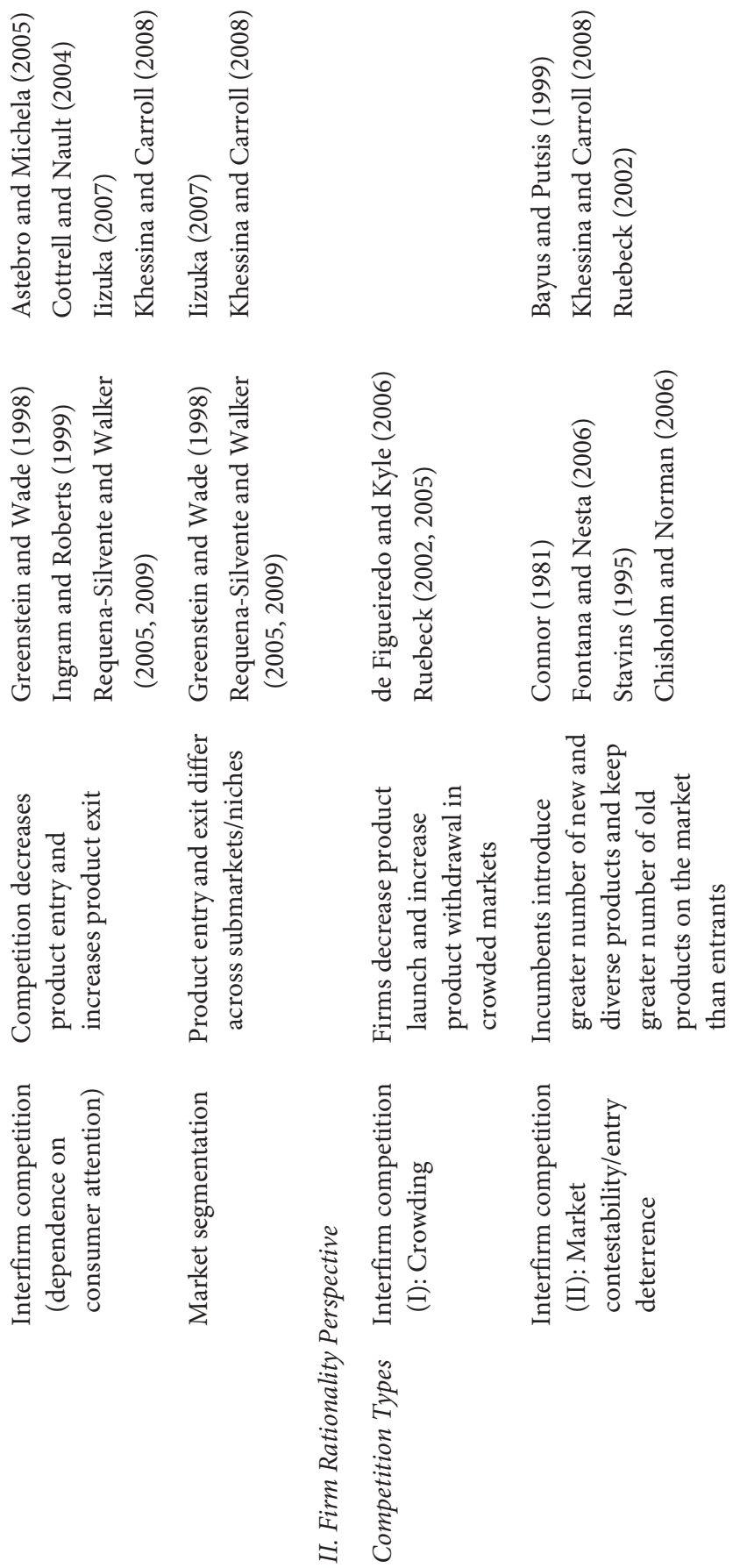
180 - The Academy of Management Annals

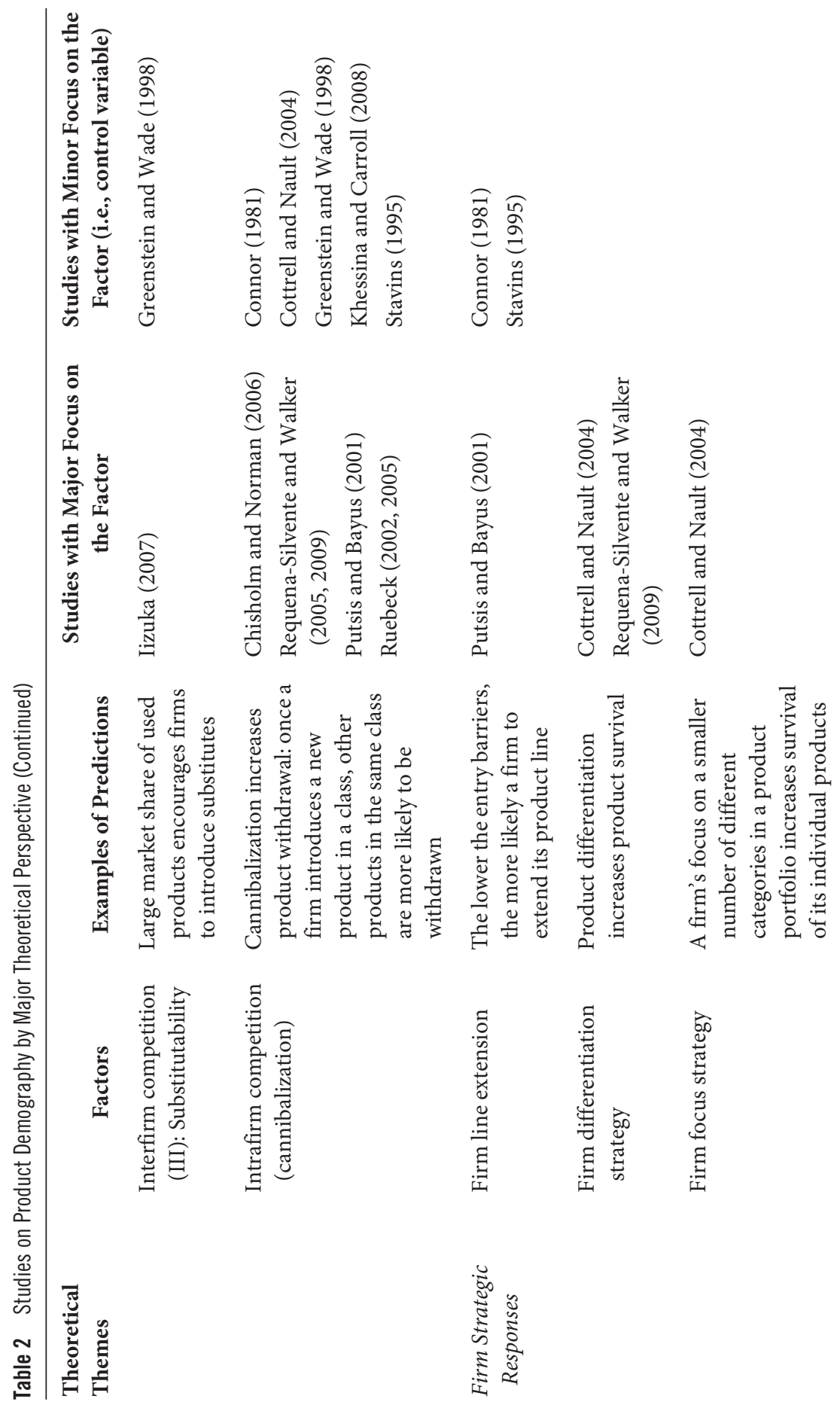



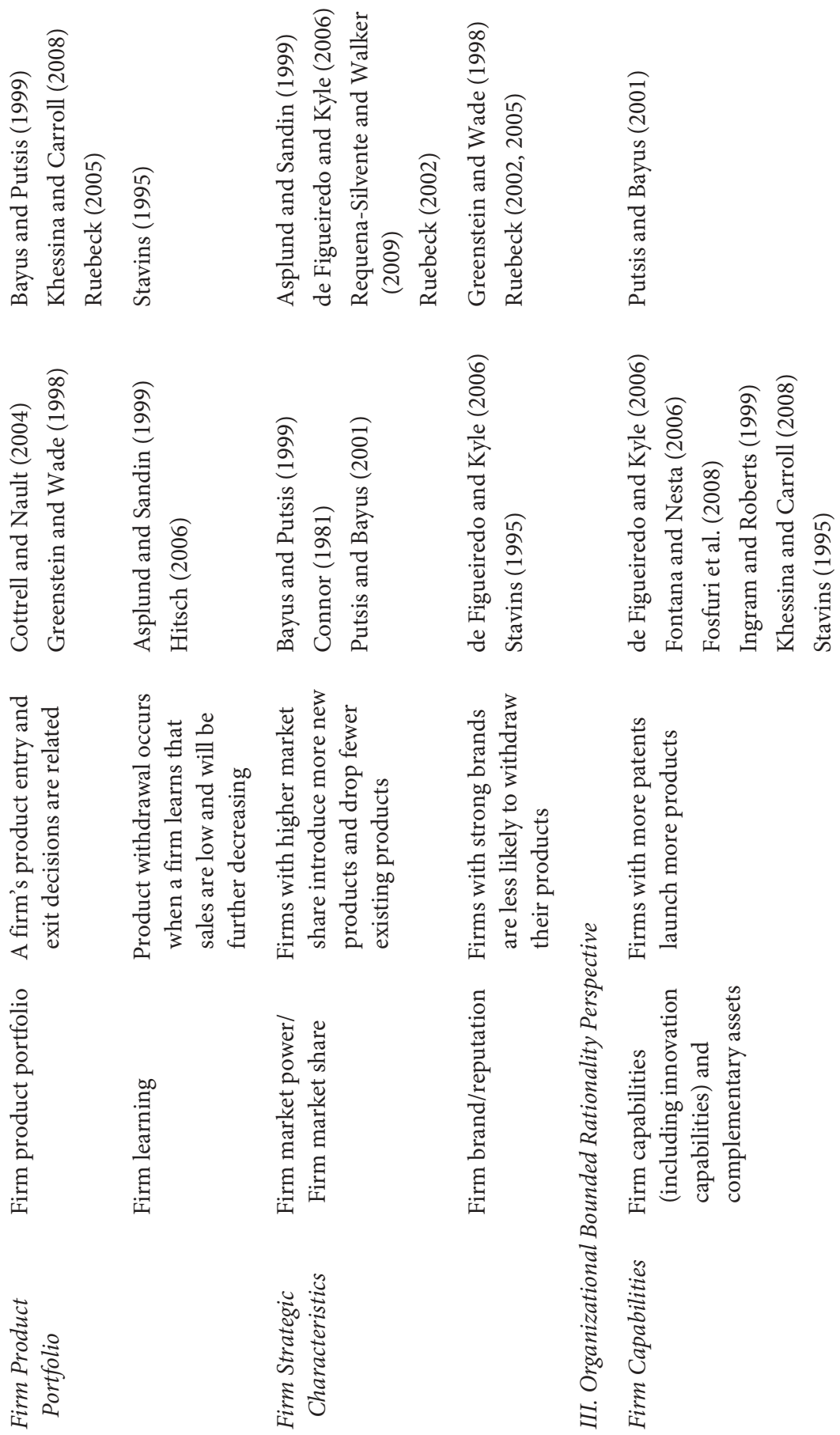
182 - The Academy of Management Annals

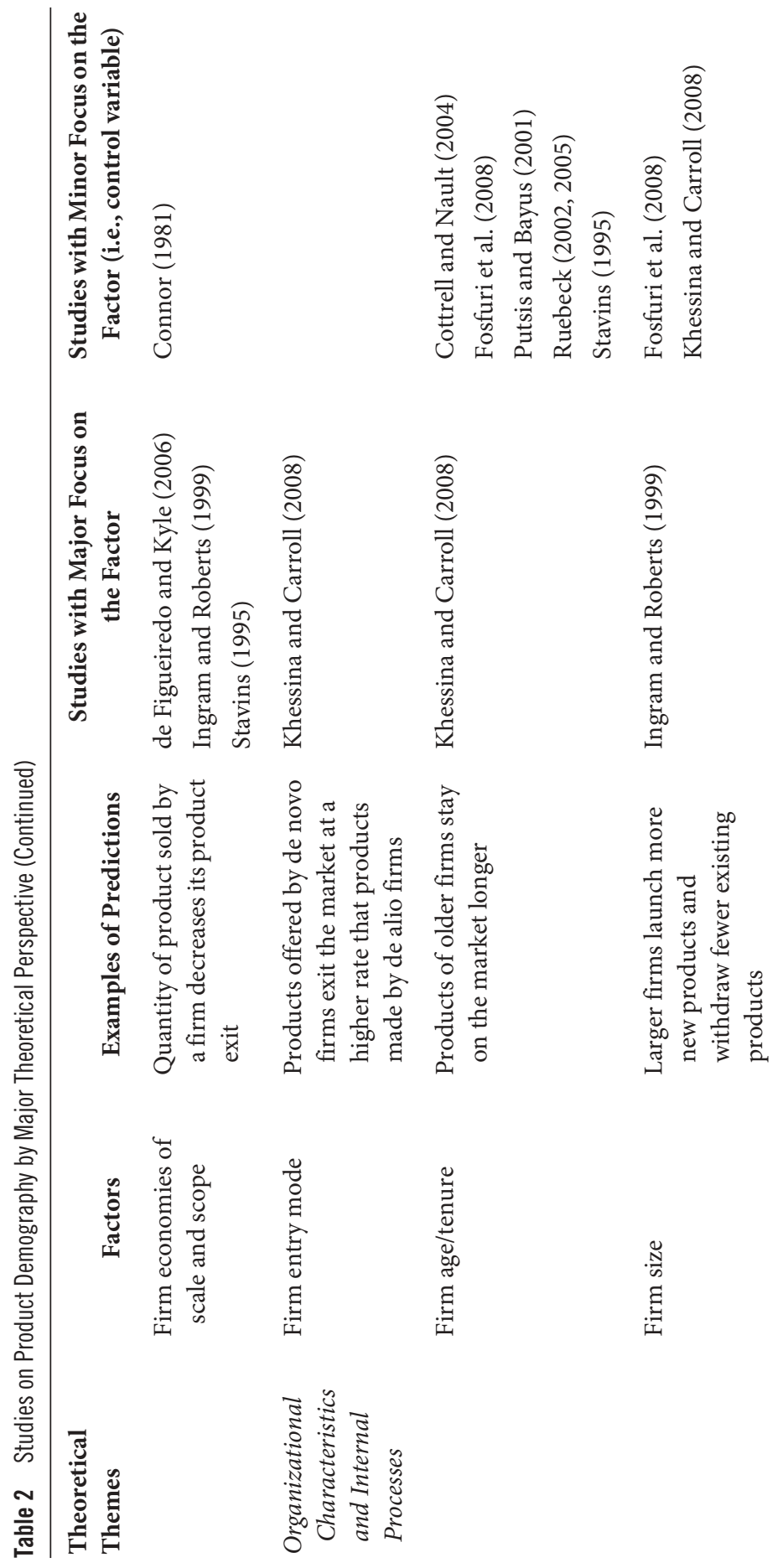


Social Lives of Products • 183
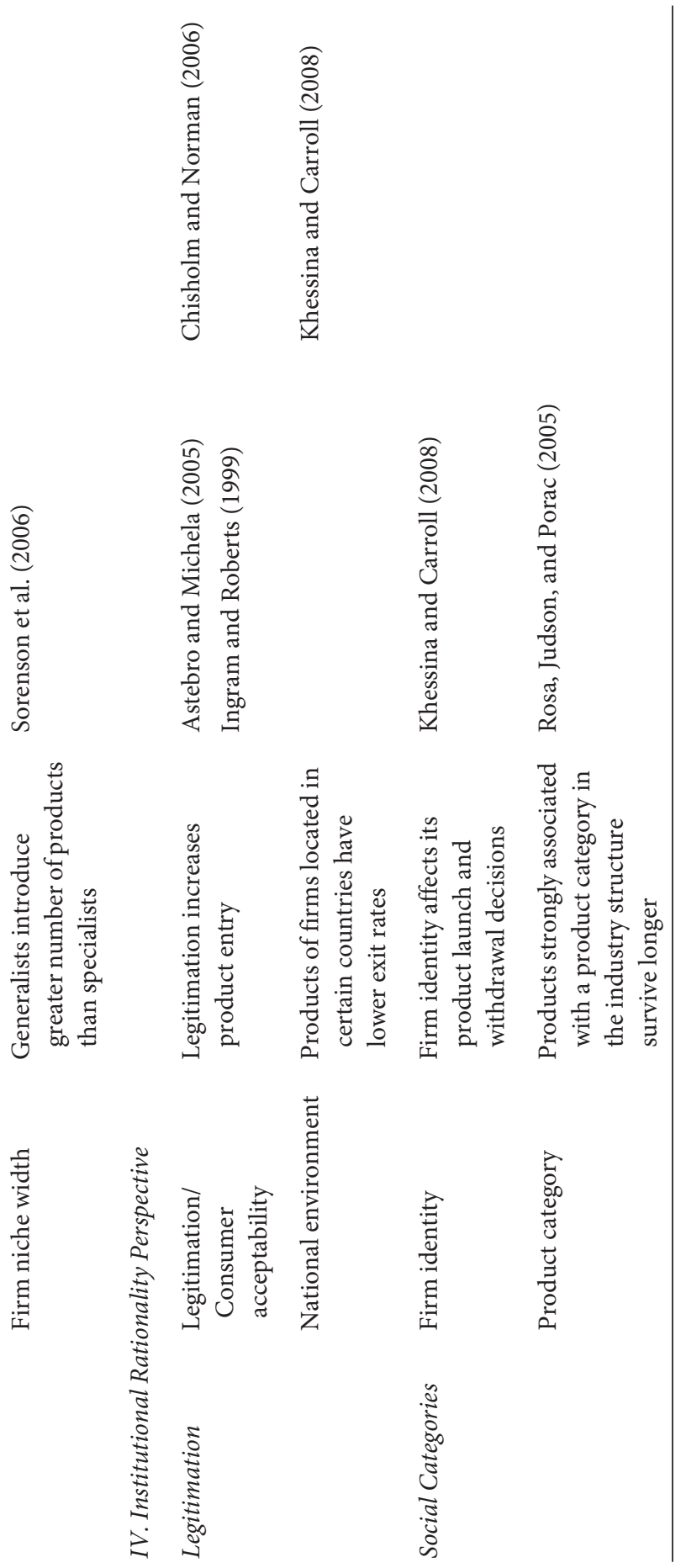
separately studies in which a given factor is a major theoretical focus and studies where the factor is used only as a control.

\section{Defining and Identifying Products}

Despite the growing number of studies in product demography, conceptual ambiguity often exists over the very definition of what a product is. We propose to clarify this issue before product demography develops further. How? Maybe it seems easy: Yes, we all know a product when we see one, and we can usually tell different types of products from each other, especially when comparing across companies. However, the issues start to get clouded once we try to identify distinct or unique products, and delineations needed to measure product launches, withdrawals, and lifetimes.

For instance, in the U.S. automobile market in 2006, Toyota offered cars with seven different general names or marques: Avalon, Camry, Camry Solara, Corolla, Matrix, Prius, and Yaris. At first glance, these would all seem to be distinct products - or almost so, given that the Camry Solara might be considered indistinct from Camry. But even within the Camry marque, we find that the company offers cars with five different sub-names: Camry CE, Camry LE, Camry Se, Camry XLE, and Camry Hybrid. These cars come equipped with different features and different price tags. A buyer can also choose different minor additional options (e.g., leather seats, air conditioning, paint color) but these would usually not involve choosing a different name product, just as year-to-year variations in the basic models often do not.

As Bayus (1998) recognizes, some of these kinds of distinctions reflect in part the possible levels of product market analysis. In studying personal-computer products, he identifies six different levels: industry (e.g., computer), product category (e.g., personal computer), product form (e.g., desktop personal computer), product technology (e.g., 16-bit CPU), product model (e.g., 286 CPU chip), and brand model (e.g., IBM PC XT). Yet, it is not clear where Bayus (1998) derived his specific hierarchy of levels from, or how general it is intended to be. It is also noteworthy that the examples he uses are not tightly hierarchical; for instance, the 16-bit CPU is not exclusive to desktop personal computers.

Bayus (1998) notes that "product" lifetimes or life cycles can be calculated at any of these levels and will typically be shorter at lower levels, with the brand model product lifetime the shortest. Higher-level product market definitions of product lifetimes (e.g., product market or product technology) entail an aggregation of entry/exit and sales data across the various relevant individual product brands of all the relevant manufacturers. Indeed, much (almost all) of the social-science research on the "product life cycle" is conducted at one of these higher levels of aggregation across many individual products and companies (e.g., generic products or product classes such as rubber tires and radial tires-see Klepper \& Simons, 2000). As Bayus (1998, 
p. 764) observes: "studies ... generally have taken indirect approaches using only aggregate data at the industry or product category level." Very little attention has been paid to the behavior of companies' specific individual products. ${ }^{3}$

\section{Products Defined}

But what exactly is a product? It might seem desirable to come up with a universal objective way (perhaps based on product characteristics) to define what constitutes a specific individual product of a company and thus what separates one product from another. But we think that this approach glosses over the fact that distinctions that matter greatly in one context or market make absolutely no difference in another. Moreover, for complex products, an almost endless number of unique possible combinations of product features exist, many of which are unrecognized by the buyer. Accordingly, the approach we advocate involves defining unique products using each company's realized definitions of products based on the distinctions the company makes in its offerings to the buyer market (see also Bayus \& Putsis, 1999; Khessina \& Carroll, 2008; Sanderson \& Uzumeri, 1997; Stavins, 1995). In other words, if the company calls it a separate product in its announcements and catalogs, then it is a separate product, and if the company does not, then it is not. This approach to defining products essentially relies on the socially constructed market identities of products. ${ }^{4}$ As with all identities, we assume that the realized product definitions are constructed to satisfy the constraints (of experts, buyers, authorities, etc.) prevailing in any particular market or context (Hannan et al., 2007); however, we also recognize that various specific audiences may differ in their assessments.

\section{Product Names}

Product-naming conventions vary a lot by context. In some contexts, such as the hard-disk-drive market, almost every important technical change defines a new product offering (in the company's eyes, as well as in the market); that is, the vast majority of the individual products listed in industry sources show no technical change over their lives. In other contexts, such as automobile manufacturing, product definitions persist even though technical characteristics sometimes change radically. The spirit of our approach agrees with that of Bayus (1998). For instance, he justifies his CPU-based definition of product brand model for personal computers on the fact that "manufacturers generally use unique brand model names for personal computers with different CPUs and incur significant expenses with the production and launch of each model ... Multiple memory, display and communication configurations typically are then possible with any brand model and can be changed at the time of purchase or later" (Bayus 1998, p. 766). However, we believe that Bayus's (1998) use of the term "brand" carries too many connotations; in hard-disk 
drives, for example, unique products are often identified only by a new product number rather than a name.

\section{Product Displacement}

In contexts where product models typically show the same technical specifications during each year, product introductions usually involve technical displacement. Another way of putting it is that any time the technology changes, the "product" changes too. For instance, in the hard-disk-drive industry, newer, higher-performance disk drives replace older ones.

A common instance of the phenomenon of product displacement (and technological change more generally) is the introduction of product "families" by multiproduct disk-drive manufacturers. Product families share certain "platforms" such as applications (whether for desktop PCs or notebooks or for certain uses like audio-video) or technological components (such as thin-film heads and thin-film disks). Although they share certain features, products within a family would nonetheless vary along dimensions such as capacity, access time, type of interface, and the like. It is common for drives in families to use one, two, three, four, or even eight platters to address different market niches. For example, products in Seagate Technology's ST4000 family of disk drives, introduced in 1985, shared the same areal density and access times, but the ST4038 had five disks and 38.17 megabytes of unformatted capacity, while the ST4026 had only four disks and 25.62 megabytes of unformatted capacity. New product families often replace older product families: Seagate's 4000 family of disk drives replaced its older 400 family of drives.

\section{Identifying and Coding Products}

In coding actual data on products in any context, analysts must be alert to exceptions to any general tendency. For example, with hard-disk drives, in a small number of cases (perhaps fewer than five percent of all "products"), technical specifications would change without a change in product name, or the product name would change without a change in technical specifications. For instance, in 1990, Maxtor listed the XT-8760E, which first shipped in 1987 (Disk Trend, 1990). In 1991 and 1992, the XT-8760EH was listed, with identical specifications (including first shipment date) to the XT-8760E; the XT-8760E was no longer mentioned. The same product also provides an example of a change in technical specification without a change in name. In 1987, the average access time for the XT-8760E was given as 26.3 milliseconds. In 1988, the access time had decreased to 24.8 milliseconds, where it remained throughout the product's life. In both cases, we would code as one product.

Data sources can also be misleading because product introductions are sometimes announced (in advance, perhaps strategically) but not delivered. For example, in 1984, International Memories listed a hard-disk-drive product, the $5650 \mathrm{H}$, that was expected to ship in 1985 but apparently did not 
because later sources do not list it. Other products might be expected to ship on a certain date but in fact get delayed. For example, Siemens's 1300 harddisk drive was originally announced to ship during the fourth quarter of 1985 , but did not ship until 1986 according to subsequent reports. (The source, Disk Trend, advised us that when there is a change in shipment information, the most recent Report is the most reliable source of information.)

Other "products" may need to be excluded because they involve the remarketing of existing products rather than unique introduction. For example, in 1996, Seiko Epson's EHDD170 hard-disk drive was actually manufactured by Integral Peripherals, which listed the same product as the 8170PA Viper 170.

\section{Components of Product Demography}

Demography is the science of populations; it studies population emergence, growth, decline, and disappearance by examining the rates of vital events such as birth and death. Any collection of elements with some unit character, social or other, can be defined as a population. Obviously, a demography of products investigates the comparable vital rates of products underlying a specified population of products. By consciously adapting the standard analytical components of demography, research on product demography could become more informative, comparative, and insightful, in our view. What are these components?

\section{Product Populations}

A product population could be specified in at least two different ways including, first, the full set of individual instances of a certain product made by a particular company (e.g., all the Nike Air Jordan Fusion 9 basketball shoes made) and still in use or circulation, and, second, as the set of distinct product offerings on sale by all companies in a specific market at a particular time (e.g., all models of basketball shoes offered by all firms in the world market). The first type of population may be useful for understanding changes in a particular product's appeal over time and the ability of its producer organization to change manufacturing and distribution in response to fluctuating demand. The second type of product population is inherently comparative, across both firms and specific products, and therefore potentially informs theories of competition and organization more directly. Therefore, we propose paying attention primarily to this second type of product population. Accordingly, we define $Q$ to be the population of all $i$ distinct products in market $S$ at time $t$.

\section{Vital Events}

Of central interest to population demographers are the rates of vital events. The primary vital events of biologically based demography consist of birth and death, with growth and migration of secondary interest. Because the female member of a biological population experiences the birth event, modeling often 
uses her as the core unit of analysis. Corporate demography conceptualizes vital events of organizational founding and mortality, as well as growth and structural transformation of organizations (Carroll \& Hannan, 2000). In corporate demography, there is no maternal requirement, so the population itself can be taken as the unit at risk to experience founding. For product demography, the vital events are the appearance and disappearance of a product on the market; also of interest are product growth rates, measured as the number of products of a particular kind shipped or sold.

In reviewing studies on product demography, it is noteworthy that the terms (words) used to describe these events vary considerably and often carry implicit agency or an implicit class of causal forces. For instance, product appearance is described at various times as product entry (Stavins, 1995), launch (Hitsch, 2006), introduction (Ingram \& Roberts, 1999), release (Fosfuri et al., 2008), and offering (Cottrell \& Nault, 2004). Product disappearance is variously called product exit (Khessina \& Carroll, 2008), withdrawal (Ruebeck, 2005), failure (Greenstein \& Wade, 1998), scrapping (Hitsch, 2006), pruning (Putsis \& Bayus, 2001), killing off (Iizuka, 2007), and turnover (Asplund \& Sandin, 1999). Time of product on the market is referred to as product life (Moral \& Jaumandreu, 2007), lifetime (Bayus, 1998), life cycle (Greenstein \& Wade, 1998), longevity (de Figueiredo \& Kyle, 2006), duration (Astebro \& Michela, 2005), and survival (Requena-Silvente \& Walker, 2009). At times, these different terms reflect a behavioral reality of a context observed by researchers (e.g., a preponderance of the disappearance events might involve a failure of a product to gain consumer acceptance), but many times we think the differences reflect implicit assumptions that analysts bring to the research, perhaps unwittingly. We attempted to draw out many of these differences in our review of the four perspectives above.

Rate models. Vital rates are typically modeled as continuous-time rate or hazard function models. For product endings, the product is treated as the unit at risk, and the 'dependent variable' is the instantaneous rate of a product's disappearance from the population, defined as:

$$
r(t)=\lim _{\Delta t \rightarrow 0} \frac{P[t<T<t+\Delta t \mid T>t]}{\Delta t},
$$

where $T$ is a random variable for the time of the disappearance event, $t$ is the lifetime or tenure of the product in the population, and $P($.$) is the conditional$ probability of the product's disappearance from the population over the interval $(t, t+\Delta t)$ given that the product was still in the population at time $t$. Although practice varies, we believe that analysts should use the continuous time framework because it more accurately reflects the actual process (rather than the structure of the data), whereby products might leave the population 
at any moment in time. For product initiations, a similar setup is typically used except that here the unit at risk is the population itself, conditional on the first product's appearance; the rate is then defined as the rate of product introduction experienced by the population. Although not yet used much for product demography, either type of event can be disaggregated further to make finer distinctions (e.g., product failure vs. product withdrawal because of replacement by an upgrade), depending on the behavioral reality of the setting and measurement precision. The resulting models are often referred to as multiple destination models. An important distinction in product endings is between those that occur simultaneously with firm disappearance and those that do not (Khessina \& Carroll, 2008).

Rate models can be estimated with a variety of data structures, including especially event-count and event-history data. For product-launch events, data might come aggregated to the year, meaning that observations often contain more than one event. One could, of course, artificially disaggregate the data and estimate the durations between events by, say, distributing events equally throughout the year (so if there are two events, the durations would be a half-year, three events, a third-year, etc.). However, a preferred course of action is to use only the information contained in the data and estimate rate models from the event-count data using appropriate estimators, such as Poisson regression and negative binomial regression.

As with event-history data analysis, event-count data are analyzed by assuming that product-launch events are governed by stochastic processes. The instantaneous rate of event occurrence (i.e., the rate at which the next product introduction happens in a population) is defined as

$$
\lambda_{n}(t)=\lim _{\Delta t \rightarrow 0} \frac{\operatorname{Prob}[Y(t+\Delta t)-Y(t) \geq 1 \mid Y(t)=n]}{\Delta t}
$$

where $Y(t)$ is a random variable denoting the cumulative number of products launched by all firms in the population by time $t$. The stochastic process of interest, the product introduction process, is $[Y(t) \mid t \leq 0]$ with state space equal to $[0,1,2, \ldots]$. The fundamental parameter of such a process is a productintroduction rate, the rate of arriving at state $n+1$ at time $t$. The analysis focuses on year-to-year variations in counts.

For product disappearance, the data typically constitute event-history data on individual products. Contemporary analysts often use the piecewise exponential function to represent variation in the timing of product disappearance from the population to allow a flexible specification of product age-dependence:

$$
r(u)=\exp \left[\sum_{p=0}^{q} m_{p} A_{p}(u)\right]
$$


where $A_{p}(u)=1$ when $u$ belongs to interval $\left(u_{p}, u_{p+1}\right)$ and 0 if otherwise. The piecewise exponential model results from a widely used strategy that splits the time-axis into time pieces determined by an analyst (Carroll \& Hannan, 2000). It specifies the product-disappearance rate $r(u)$ as a function of product longevity or tenure $(u)$ in the population, and other measured covariates $(X)$. The general class of models estimates has the form:

$$
\ln r(u, t)=m_{p}+\gamma X_{i t},
$$

where $m_{p}$ denotes tenure-specific effects, and $X_{i t}$ summarizes time-varying covariates. Parameters are frequently estimated using the method of maximum likelihood as implemented with a user-defined routine in STATA (Sørensen, 1999). To estimate rate models with time-varying covariates, "splitspell" data are constructed, breaking observed durations in year-long periods with the values of covariates updated every year.

Product growth rates can be modeled as change in the number of particular kinds of products made or sold by firms. If we denote firms by $k$ and products by $i$, then a growth model could be specified of the general form:

$$
\ln \left[N_{i k t} / N_{i k t-1}\right]=a_{0}+a_{1} N_{i k t}+a_{2} Z_{i k t}+e,
$$

where $N$ represents the number of products of a particular kind made by a particular firm, the $Z$ variable is a covariate, and $e$ is a random disturbance. Note that this equation models the full set of individual instances of a certain product made by a particular company, which we mentioned above as a different way to approach product demography.

\section{Two Illustrative Populations}

To show the viability of collecting product data in our proposed manner, and to hint at some of the intriguing facts it might generate, we present several comparisons of data from our own research on two industries: the floppy disk drive (FDD) and the optical disk drive (ODD). Sources and descriptions of data can be found in McKendrick and Wade (forthcoming) and Khessina and Carroll (2008).

Figure 1 shows the annual number of product entries and exits for each population (Figure 1a shows FDD products and Figure 1b shows ODD products), as well as the trajectories of product density, a count of the number of products on the market. Both populations show ample demographic activity, and in both cases numbers of exits commonly track entries over time. In both populations, product density rises steadily for the first 15 years or so, but the rise is slightly more rapid for floppy drives. The FDD population starts earlier and represents a more mature population. So, it is not surprising that we see a leveling off and then precipitous decline for it that is not yet evident for ODD 

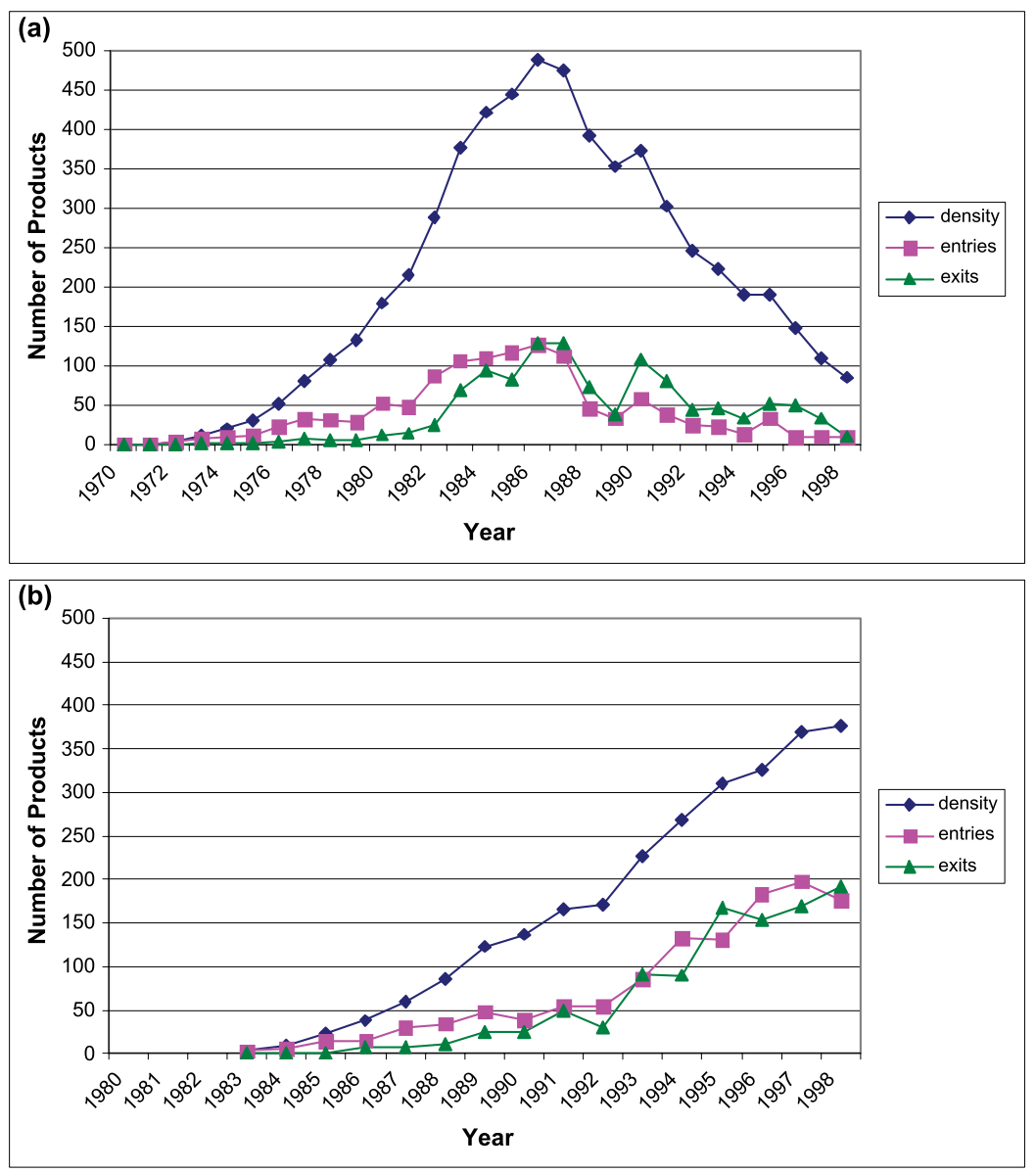

Figure 1 (a) Product Density, Entries, and Exits in the Worldwide FDD Industry, 1970-1998; (b) Product Density, Entries, and Exits in the Worldwide ODD Industry, 1983-1998.

products. We do find it interesting that the FDD population maintains a considerably higher ongoing "churn" level, average number of entries and exits for a given density size, often approaching 25 percent.

Figure 2 shows plots of product density against firm density for the two populations. The most remarkable feature here is the close correspondence of the two densities, and the somewhat similar numbers for the two populations. Firm density does peak before product density in the FDD population, and this may occur with the ODD population as well, but the data do not yet show a decline in optical product density.

In Figure 3, we plot product density alongside total industry revenue (measured in millions of dollars). In floppies, revenues peak almost simultaneously 


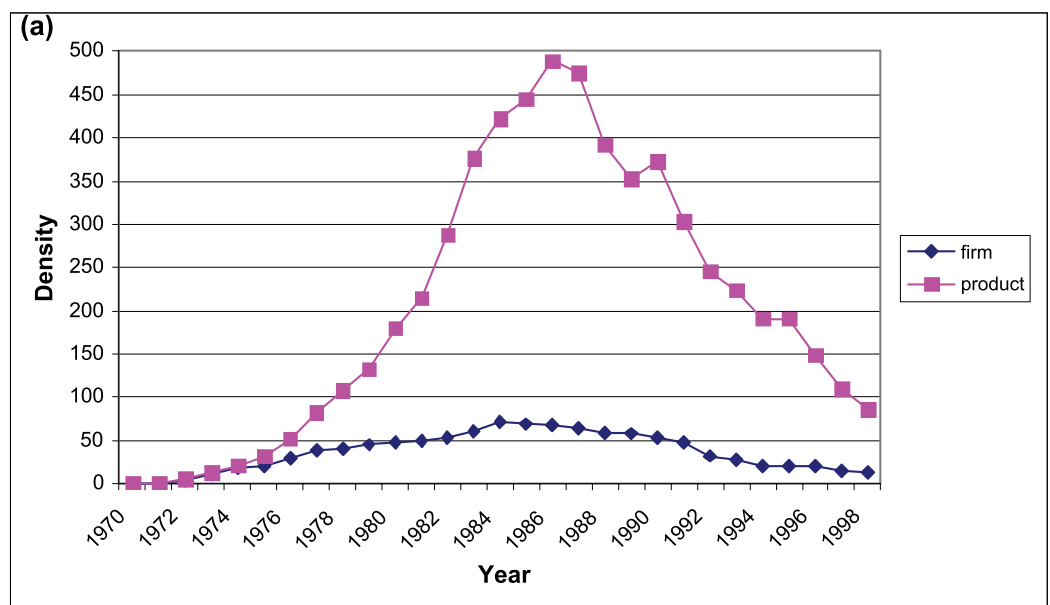

(b)

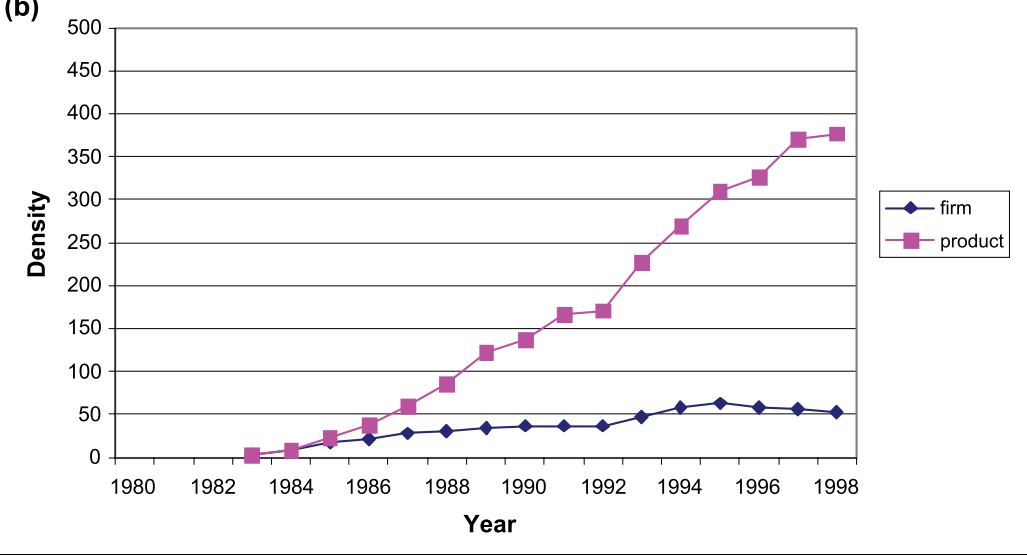

Figure 2 (a) Firm and Product Densities in the Worldwide FDD Industry, 1970-1998; (b) Firm and Product Densities in the Worldwide ODD Industry, 1983-1998.

with product density. That does not look to be the case with optical drives, but the process may have not unfolded yet.

\section{Reconciling Perspectives: A Research Program for Management Analysts}

The review of theoretical ideas and perspectives used above in analyzing product demography might seem overwhelming, containing as it does many possible explanatory factors. In going forward, one basic question to ask is does it make sense to try to use them all, even if just for identifying empirical controls? Although our position breaches the idealized rhetoric of integrative and multidisciplinary social science, we do not think so. In fact, at this stage in the research program, we believe that such an approach would actually be counterproductive. Why? 

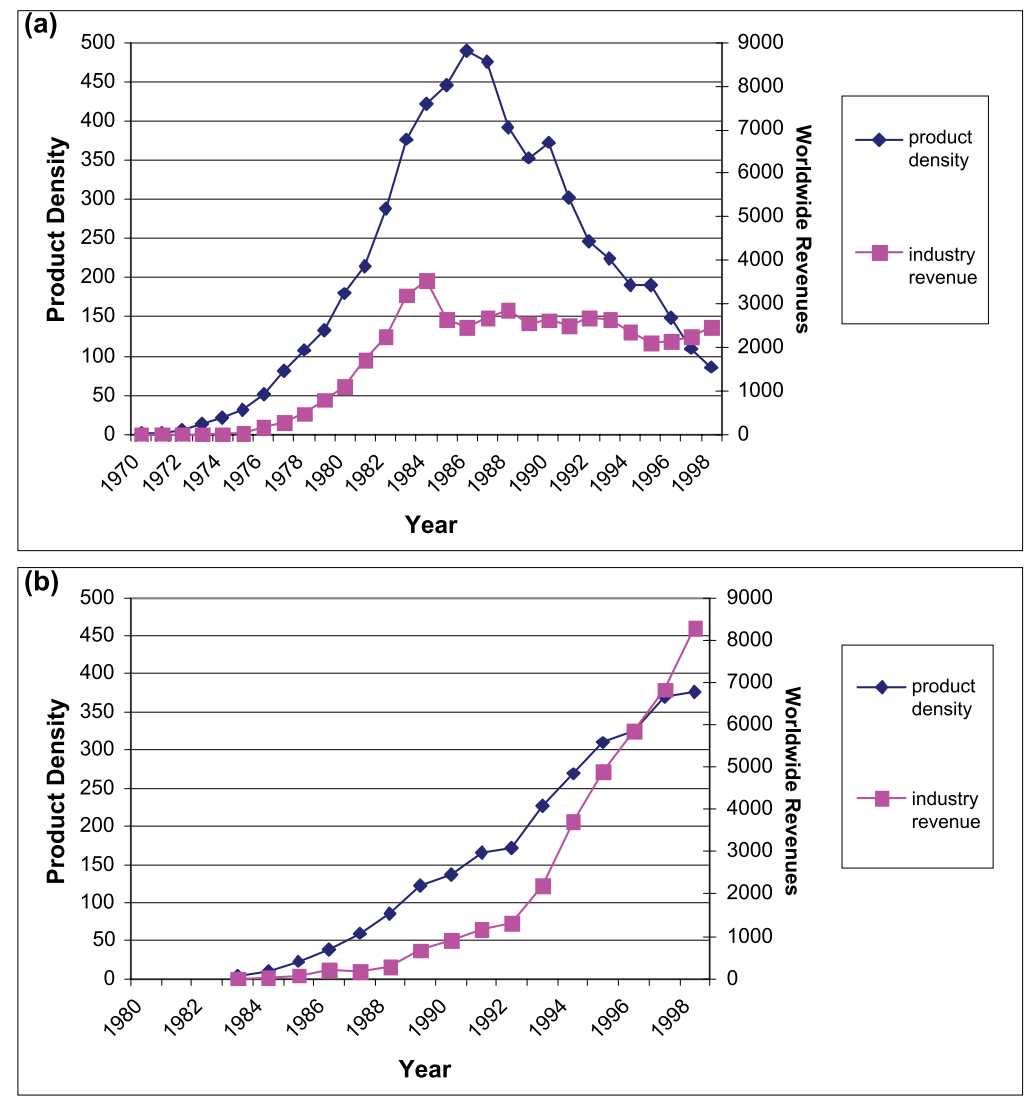

Figure 3 (a) Product Density and Worldwide Revenues (in Millions of US\$) in the FDD Industry, 1970-1998; (b) Product Density and Worldwide Revenues (in Millions of US\$) in the ODD Industry, 1983-1998.

First, the explanatory status of many seemingly plausible mechanisms and independent variables remains unknown at this point. We do not know which explanations carry the most weight, that is, which operate in many contexts and which exert the greatest explanatory impact. We suggest what is needed most at this stage in product demography are studies showing positive evidence, demonstrating the plausibility of some perspectives and lines of theory. For some ideas, this means producing a first or second shred of positive evidence. For other ideas, it means strengthening the evidence base-for instance, many of the studies reviewed above may not adequately correct for possible endogeneity of the key regressors. Negating other ideas through control variables seems less important than strengthening the confirming evidence, especially when obscure controls are involved. It also seems quite 
premature to try to impose order by sorting out systematically which ideas and theories are supported by evidence and prune away the others. ${ }^{5}$

Second, the product demography of certain types of firms and industries is better understood by a specific theoretical perspective, which can be applied and extended in a logically consistent and coherent fashion. Theories develop when pressed to account for new and possibly conflicting evidence. Allowing apparent anomalies to be readily explained by resort to a different-possibly inconsistent-theory is just too easy. Pushing a theory hard is also the best way to understand its limits.

We suspect, for instance, that in many firms there are classes of products that exhibit codependence in behavior similar to what we have been discussing for the firm-rationality perspective, but that this codependence does not stretch beyond the class to other products. For instance, at IBM it may be that data-storage products were linked to each other's fates but that these bore little or no relation to computers and certainly not to typewriters. The extent of such product-behavior codependence and how it relates to product classes and firm organization represents a potentially important direction for theory and research. But it does not seem fruitful for those interested in exploring it to be required to run through the long list of control variables cited above to prove their point.

Third, it may also be that specific theoretical perspectives pertain mainly to particular times or phases of an industrial setting, including those related to cross-national differences in development and institutions. Consider also the possible transformation of an industrial setting from one kind of rationality to another. Do contexts shift or evolve from one kind of rationality to another, and if so, how and why?

In sum, we believe that the general problem with attempting to control for the multitude of factors already on the product demography menu is that the menu will always be potentially incomplete, and the various "dishes" listed on it should not always be eaten at the same time because of clashes among inconsistent and even contradictory assumptions. Accordingly, knowledge does not automatically cumulate in a way that tells us when to invoke certain explanations and when to invoke others. Rather than focus on adding to the menu or worrying about its completeness in any specific study, we think that at this stage in the development of product demography, analysts should be trying to develop cogent theoretical rationales and tease out novel explanations and mechanisms.

\section{An Example}

A good example here would seem to be scientific publishing and journals as products. It is our strong impression that for many decades, scientific journals operated pretty much as independent products, and their fates depended on characteristics of their fields and their appeal as reflected in subscription 
numbers; that is, journals behaved by principles of market rationality, as outlined above. But with the development of electronic publishing, this seems to have changed dramatically. Journals now reside in cyber space and are sold to libraries and other service providers in bundles, often with hundreds of other journals, all for a single price. This means that publishers worry about the appeal of the bundle and try to manage individual products so as to make the bundle attractive. As a result, individual journal subscriptions matter less today. The bundles of journals behave as firm rationality by the publishing houses. In our view, analysts should be free to use the perspective for their context that provides greatest insight, without being encumbered to address all those other previously significant factors from other studies that do not appear to show insight or be compelling controls.

In general, our view is that the most important thing now for product demographers is to build the evidence pile before trying to sort it out. Each study should use what is deemed important and novel for its setting and context, both in terms of explanations and controls. After the findings of a number of studies accumulate, then we can see how to integrate and reconcile them. Along the way, some currently open avenues may never develop and live up to their possible promise. For instance, studies measuring the impact of individual product attributes might consistently show stronger empirical findings than those assessing product-portfolio considerations. Or, a factor such as product-entry order may never show consistent or interpretable results. Spending time and effort trying to control for all these variables in advance of their demonstrated potential value represents a misguided adventure in an unrealistic, fantasized scientific land, in our view.

\section{Criteria for Programmatic Studies}

What criteria, then, should be used in designing and evaluating research on product demography? We think answers to the question would do well to be developed in reference to Figure 4, a two-by-two table locating research studies along two dimensions (of course, the dichotomies are drawn artificially on the continuous dimensions to highlight differences).

The horizontal dimension represents the degree of detail and measurement depth in the data used in a study. The cells on the left (labeled A and C) contain studies that possess much less detail and depth than those in the cells on the right. This means that the studies on the right (cells B and D) use better (more precise and more reliable) measures, control for more extraneous other factors, and identify the contexts more clearly. If we think of a study as about the association between a possible cause $\mathrm{X}$ and an outcome $\mathrm{Y}$, then the studies on the right show higher and more convincing rigor in associating $\mathrm{X}$ with $\mathrm{Y}$.

The vertical dimension represents differences in the theoretical relevance of a study. By theoretical relevance, we mean here the importance of a possible $\mathrm{X}-\mathrm{Y}$ association to a theoretical research program (Lakatos, 1978). The 


Theoretical
relevance.
Importance
of X-Y
association to
theory
development.

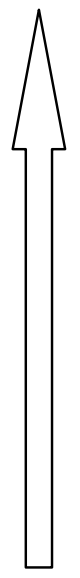

Data detail and depth of measurement.

Rigor in associating $\mathrm{X}$ and $\mathrm{Y}$.

Figure 4 Characteristics of Research Designs Exploring the X-Y Relation.

program, of course, is of the analysts' choice. We have in mind here two kinds of programs - those driven by prior prominence where the importance of $\mathrm{X}$ is well established in other research contexts, and those where $\mathrm{X}$ is a pivotal conceptual component in a newly developed mechanism or theory. Studies in the upper cells (A and B) possess the potential to change dramatically the way analysts think about a mechanism or theory and its explanatory value.

Now, the point of this figure may seem trivial to some because everyone will agree that the best location without a doubt is cell B. The ideal study has great theoretical relevance and uses detailed data to make a convincing case in its conclusions. Similarly, cell C will likely generate little debate because its studies show little or no value. No one will advocate a study of little theoretical relevance that does not convince skeptics about its conclusions because the data are limited. However, we suggest that the social-sciences studies of the B-cell variety are quite rare and that those of the $\mathrm{C}$-cell variety are not given much attention. Moreover, we suggest that for newly emergent research programs, such as product demography, it may be impossible to execute a B-cell study, simply because all the potentially important control variables have not yet been identified.

As a theoretical idea progresses beyond its initial formulation, the demands for rigor increase. Early on, the idea needs to muster some evidence that it is plausible, that it might be worth exploring further and developing. Typical 
early studies simply demonstrate empirically the plausibility of the idea. Once this is achieved, then analysts ask how strong it is, how much explanatory value it has. Studies then typically seek to understand how robust the idea is, how many contexts it might apply to, how it compares to other explanations of the same phenomena, and what factors might mediate or dominate its operation. In terms of the figure, this progression involves moving from cellA studies to cell D and occasionally to cell B.

For contemporary product demography, a research area still in its infancy, the important point to recognize is that research programs often need to start in cell $\mathrm{A}$, and may need incubation before being subjected to the criticisms inherent in cells B and D. The costs of moving too quickly out of cell A are conceptual and theoretical underdevelopment-sterility, in other words. For these reasons, we believe that the focus at the moment for those studying product demography should be to develop theoretical ideas and mechanisms and to try to demonstrate their plausibility empirically-but also to leave excessive concerns over rigor for a later stage.

As an example, we would point to organizational ecology (see Carroll \& Hannan, 2000), a theoretical research program in organizational sociology that has enjoyed success and that many believe has produced cumulative knowledge. Within organizational ecology, we could consider any of several theory fragments; a prominent one is density dependence. This program provides a model of long-term theoretical evolution driven by the two forces of legitimation and competition. The empirical evidence supporting the model consists of two findings of non-monotonic relationships between counts of organizational density on the one hand, and rates of organizational founding (the first relation) and organizational mortality (the second relation) on the other hand. Throughout its development, the model has grown from an initial idea to a well-established empirically supported theory with lots of potential nuances. While it has been subjected to ample criticism, including some rather severe in nature, we would suggest that its early development benefited from a pronounced focus on the original theoretical insights and ideas behind it, rather than the myriad of other possible factors that might account for organizational founding and mortality. That is, early studies tried mainly to demonstrate the plausibility of the novel aspects of the legitimation and competition stories of the model, rather than trying to control for all other potential explanatory variables. Without this early period, we doubt that the model would have developed as thoroughly as it has.

It is perhaps instructive to compare our proposed research program for product demography to two other calls for reorienting management research generally. Daft and Lewin (1990) advocate abandonment of normal science and its theoretically driven research designs for the study of management (especially organizations) because they think such an approach is premature in imposing convergent thought. In its place, they propose a more open-ended 
range of inquiry that includes a marked emphasis on performance outcomes, a goal of reducing equivocality, and the use of heretical research designs. Hambrick (2007) pleads for a greater appreciation of management-oriented studies that pursue goals other than the advancement of novel theory. He is especially forceful in advocating empirical research that advances important new facts. ${ }^{6}$

On the one hand, our proposal agrees with the views of both of these essays at a general level. We are certainly in favor of opening up new lines of inquiry and theory on management and the use of whatever methods make sense to do so (some of this would be consistent with our cell A). We also agree that such research often tends to be underappreciated, still (we say so in A). We also recognize the great value that might come from empirical studies that produce rigorous facts and empirical associations (this might be considered our cell D). On the other hand, we disagree with some of their finer lines of argumentation. Compared to Daft and Lewin (1990), we are not so quick to abandon conventional methods and are not at all convinced that doing so will generate research more likely to produce stunning insights. We also reject the primacy of performance-oriented outcomes; indeed, we think that such a constraint is itself often an intellectual straitjacket. Finally, while we do not advocate increasing equivocality in and of itself, we do recognize that research in quadrant A will sometimes do that; in the early stages of a research program, we are willing to live with such uncertainty in return for plausible insight and intellectual excitement. Our biggest difference with Hambrick (2007, p. 1349) can be seen by noting some of the characteristics of what he calls an interesting fact: "... all obvious covariates and endogenous relationships have been controlled for; and the effect size is big." In other words, he is insisting on relevance and high rigor. As with equivocality, we do not endorse low rigor in and of itself, but we do think that there are times in a research program when insight and excitement take priority. The evidence pile we propose constructing at this stage is clearly not up to Hambrick's standards of rigor.

Perhaps the major distinction between our proposal and these other two is about the specificity of programmatic applicability. We are making suggestions that are intended to apply to an early stage of a research program defined by certain phenomena. We would never suggest that these principles should apply to other, especially mature-stage, research programs.

\section{Conclusion}

Product demography, the study of products' social lives, remains underdeveloped both theoretically and empirically. Yet its potential importance seems high, given the central place that products occupy in major theoretical frameworks of strategy and management. In this essay, we have tried to organize the extant body of research on product demography and to offer some suggestions for building cumulative knowledge going forward. 
Research on product demography currently originates in several disciplines and offers a disparate array of possible explanatory factors. However, we think most of these explanations can be classified into four different theoretical perspectives, each carrying along its own set of (often different) assumptions. We label these as rationalities about markets, firms, organizations, and institutions. We find valuable research in each, but suggest that the last two hold more unfulfilled promise at the moment.

Our proposals for future research are intended mainly to make studies more comparable, and to develop greater understanding of what are the most valuable ideas. Among these, some are rather mundane technical suggestions, such as studying complete populations of unique products and using continuous time-hazard models for estimating rates of vital events. Others, such as defining products as socially constructed by their producing firms, involve more assumptions about what is important for comparative analysis, and will likely prove more controversial. Another set of suggestions, about how to design and evaluate research given the current degree of programmatic development, we imagine will attract some strong dissent-we are essentially arguing that analysts should now worry mainly about developing cogent theoretical ideas and offering some positive evidence in their support rather than worry about comprehensiveness in controls or integrating diverse multidisciplinary approaches.

No matter how future analysts proceed, we believe that all the pieces are in place for product demography to cohere into a productive and insightful research area that informs many aspects of management theory and practice. The theoretical ideas, the models and methods, and the data are all currently within easy reach of most analysts. The time is right for social scientists to gather the pieces, attempt to assemble them anew, and see what kinds of structures emerge. We eagerly await the resulting insights.

\section{Acknowledgments}

We appreciate the support of the Graduate School of Business at Stanford University and the Johnson School of Management at Cornell University. Helpful comments on an earlier draft came from John de Figueiredo, Sunasir Dutta, Tamar Kreps, Andrew Peterman, and Jim Wade. We also appreciate comments and editorial assistance from Art Brief and Jim Walsh.

\section{Endnotes}

1. It is important to recognize one key difference between human demography and product demography, namely, the almost universal positive value associated with longevity of humans. For products, a firm may at times be better off with shorter product longevities, as we discuss below.

2. In a study of jazz recordings, Phillips (2009) argues that the reverse should be true when there is a premium placed on creativity and the producer is not from the 
social mainstream. He claims that the audience interprets a recording as more creative when it originates from a socially disconnected place.

3. However, notably spectacular failures do get some play (see Hartley, 2005; Ricks, 2006).

4. We do not intend that the definition of product here be restricted to only tangible outcomes of a firm's production system. Although it may make measurement more difficult, we think that service providers can also be seen as delivering "products," to the extent that a fixed bundle of particular services is viewed as discrete entity.

5. However, we certainly think that sorting out the supported ideas would be useful once a stronger evidentiary foundation has been built.

6. Although he does not cite it, Hambrick's (2007) essay reminds us of Simon's (1968) earlier call for social science to produce more facts worthy of explanation, rather than theoretical explanations that account for trivial facts.

\section{References}

Abernathy, W.J., \& Utterback, J.M. (1978). Patterns of industrial innovation. Technology Review, 80, 41-47.

Amit, R., \& Schoemaker, P. (1993). Strategic assets and organizational rent. Strategic Management Journal, 14, 33-46.

Asplund, M., \& Sandin, R. (1999). The survival of new products. Review of Industrial Organization, 15, 219-237.

Astebro, T., \& Michela, J.L. (2005). Predictors of survival of innovations. Journal of Product Innovation Management, 22, 322-335.

Bayus, B.L. (1998). An analysis of product lifetimes in a technologically dynamic industry. Management Science, 44, 763-775.

Bayus, B.L., \& Putsis, W.P., Jr. (1999). Product proliferation: Analysis of product line determinants and market outcomes. Marketing Science, 18, 137-153.

Bonanno, G. (1987). Location choice, product proliferation and entry deterrence. Review of Economic Studies, 54, 37-45.

Boulding, W., \& Christen, M. (2003). Sustaining pioneering advantage? Profit implications of market entry order. Marketing Science, 22, 371-392.

Bridges, E., Kim, E.C.K., \& Briesch, R.A. (1995). A high-tech product market share model with customer expectations. Marketing Science, 14, 61-81.

Carroll, G.R., \& Hannan, M.T. (2000). The demography of corporations and industries. Princeton, NJ: Princeton University Press.

Chisholm, D.C., \& Norman, G. (2006). When to exit a product: Evidence from the U.S. motion-picture exhibition market. American Economic Review, 96, $57-61$.

Connor, J.M. (1981). Food product proliferation: A market structure analysis. American Journal of Agricultural Economics, 63, 607-617.

Cottrell, T., \& Nault, B.R. (2004). Product variety and firm survival in the microcomputer software industry. Strategic Management Journal, 25, 1005-1025.

Daft, R.L., \& Lewin, A.Y. (1990). Can organizational studies break out of the normal science straitjacket? Organization Science, 1, 1-9.

Disk/Trend (1990). Disk/Trend report: Rigid disk drives. Mountain View, CA: Disk/ Trend, Inc. 
de Figueiredo, J.M., \& Kyle, M.K. (2006). Surviving the gales of creative destruction: The determinants of product turnover. Strategic Management Journal, 27, 241-264.

de Figueiredo, J.M., \& Silverman, B.S. (2007). Churn baby churn: Strategic dynamics among dominant and fringe firms in a segmented industry. Management Science, 53, 632-650.

Fontana, R., \& Nesta, L. (2006). Product entry in a fast growing industry: The LAN switch market. Journal of Evolutionary Economics, 16, 45-64.

Fosfuri, A., Giarratana, M.S., \& Luzzi, A. (2008). The penguin has entered the building: The commercialization of open source software products. Organization Science, 19, 292-305.

Greenstein, S.M., \& Wade, J.B. (1998). The product life cycle in the commercialmainframe computer market, 1968-1982. The Rand Journal of Economics, 29, 772-789.

Hambrick, D.C. (2007). The field of management's devotion to theory: Too much of a good thing? Academy of Management Journal, 50, 1346-1352.

Hannan M.T., Pólos, L., \& Carroll, G.R. (2007). The logics of organizational theory: Audiences, codes and ecologies. Princeton, NJ: Princeton University Press.

Hartley, R.F. (2005). Marketing mistakes and successes (10th ed.). New York: Wiley.

Hitsch, G.J. (2006). An empirical model of optimal dynamic product launch and exit under demand uncertainty. Marketing Science, 25, 25-50.

Hsu, G. (2006). Jacks of all trades and masters of none: Audiences' reactions to spanning genres in feature film production. Administrative Science Quarterly, 51, $420-450$.

Iizuka, T. (2007). An empirical analysis of planned obsolescence. Journal of Economics and Management Strategy, 16L, 191-226.

Ingram, P., \& Roberts, P.W. (1999). Sub-organizational evolution in the U.S. pharmaceutical Industry. In J. Baum \& B. McKevely (Eds.), Variations in organization science (pp. 155-168). Thousand Oaks, CA: Sage.

Jovanovic, B., \& MacDonald, G.M. (1994). The life cycle of a competitive industry. Journal of Political Economy, 102, 322-347.

Khessina, O.M. (2006). Direct and indirect effects of product portfolio on firm survival in the worldwide optical disk drive industry, 1983-1999. In J.A.C. Baum, S.D. Dobrev, \& A. van Witteloostujin (Eds.), Ecology and strategy: Advances in strategic management (Vol. 23, pp. 591-630). Oxford: JAI.

Khessina, O.M., \& Carroll, G.R. (2008). Product demography of de novo and de alio firms in the optical disk drive industry, 1983-1999. Organization Science, $19,25-38$.

Kidder, T. (1982). The soul of a new machine. New York: Little-Brown.

Klepper, S. (1996). Entry, exit, growth, and innovation over the product life cycle. American Economic Review, 86, 562-583.

Klepper, S., \& Simons, K.L. (2000). The making of an oligopoly: Firm survival and technological change in the evolution of the U.S. tire industry. Journal of Political Economy, 108, 728-760.

Kuester, S., Homburg, K., \& Robertson, T.S. (1999). Retaliatory behavior to new product entry. Journal of Marketing, 63, 90-106.

Lakatos, I. (1978). The methodology of scientific research programmes: Philosophical papers Volume 1. Cambridge, England: Cambridge University Press. 
Lambkin, M., \& Day, G.S. (1989). Evolutionary processes in competitive markets: Beyond the product life cycle. Journal of Marketing, 53, 4-21.

Levinthal, D.A., \& Purohit, D. (1989). Durable goods and product obsolescence. Marketing Science, 8, 35-56.

McGahan, A.M., Argyres, N., \& Baum, J.A.C. (2004). Context, technology and strategy: Forging new perspectives on the industry life cycle. Advances in Strategic Management, 21, 1-21

McKendrick, D.G., \& Wade, J.B. (forthcoming). Frequent incremental change, organizational size and mortality in high-technology competition. Industrial and Corporate Change.

McKendrick, D.G., Jaffee, J., Carroll, G.R., \& Khessina, O.M. (2003). In the bud? Analysis of disk array producers as a (possibly) emergent organizational form. Administrative Science Quarterly, 48, 60-93

Moral, M.J., \& Jaumandreu, J. (2007). Automobile demand, model cycle and age affects. Spanish Economic Review, 9, 193-218.

Phillips, D.J. (2009). Jazz and the disconnected: City structural disconnectedness and the emergence of the jazz canon (1897-1933). Unpublished manuscript, ChicagoBooth School, University of Chicago.

Porter, M. (1979). How competitive forces shape strategy. Harvard Business Review, 57, 137-145.

Porter, M.E. (1980). Competitive strategy: Techniques for analyzing industries and competitors. New York: The Free Press.

Putsis, W.P., Jr., \& Bayus, B.L. (2001). An empirical analysis of firms' product line decisions. Journal of Marketing Research, 38, 110-118.

Randall, T., Ulrich, K., \& Reibstein, D. (1998). Brand equity and vertical product line extent. Marketing Science, 17, 356-379.

Requena-Silvente, F., \& Walker, J.T. (2005). Competition and product survival in the UK car market. Applied Economics, 37, 2289-2295.

Requena-Silvente, F., \& Walker, J.T. (2009). The survival of differentiated products: An application to the UK automobile market. The Manchester School, 77, 288-316.

Ricks, D.A. (2006). Blunders in international business (4th ed.). London: Blackwell.

Rosa, J.A., Judson, K.M., \& Porac, J.F. (2005). On sociocognitive dynamics between categories and product models in mature markets. Journal of Business Research, $58,62-69$.

Rosa, J.A., Porac, J.F., Runser-Spanjol, J., \& Saxon, M.S. (1999). Sociocognitive dynamics in a product market. Journal of Marketing, 63, 64-77.

Ruebeck, C.S. (2002). Interfirm competition, intrafirm cannibalization and product exit in the market for computer hard disk drives. Economic and Social Review, $33,119-131$.

Ruebeck, C.S. (2005). Model exit in a vertically differentiated market: Interfirm competition versus intrafirm cannibalization in the computer hard disk drive industry. Review of Industrial Organization, 26, 27-59.

Sanderson, S.W., \& Uzumeri, M. (1997). The innovation imperative. Chicago: Irwin.

Schmalensee, R. (1978). Entry deterrence in the ready-to-eat breakfast cereal industry. Bell Journal of Economics, 9, 305-327.

Sen, S., \& Bhattacharya, C.B. (2001). Does doing good always lead to doing better? Consumer reactions to corporate social responsibility. Journal of Marketing Research, 38, 225-244. 
Shankar, V. (1999). New product introduction and incumbent response strategies: Their interrelationship and the role of multimarket contact. Journal of Marketing Research, 36, 327-344.

Shankar, V., Carpenter, G.S., \& Krishnamurthi, L. (1999). The advantages of entry in the growth stage of the product life cycle: An empirical analysis. Journal of Marketing Research, 36, 269-276.

Simon, H.A. (1968). On judging the plausibility of theories. In B. van Roostelaar \& J.F. Staal (Eds.), Logic, methodology and philosophy of science III (pp. 439-459). Amsterdam: North-Holland.

Sørensen, J.B. (1999). Stpiece: A program for the estimation of piecewise-constant rate hazard models in STATA 6.0, unpublished ado-file. University of Chicago: Graduate School of Business.

Sorenson, O., McEvily, S., Ren, C.R., \& Roy, R. (2006). Niche width revisited: Organizational scope, behavior and performance. Strategic Management Journal, 27, 915-936.

Spence, A.M. (1976). Product selection, fixed costs and monopolist competition. Review of Economic Studies, 43, 217-235.

Stavins, J. (1995). Model entry and exit in a differentiated-product industry: The personal computer market. Review of Economics and Statistics, 77, 571-584.

Williamson, O.E. (1975). Markets and hierarchies: Analysis and antitrust implications. New York: The Free Press.

Zuckerman, E. (1999). The categorical imperative: Securities analysts and the illegitimacy discount. American Journal of Sociology, 104, 1398-1438. 